\title{
Böhmit a doprovodná zeolitová mineralizace ze Soutěsek u Děčína (Česká republika)
}

\author{
Böhmite and accompanying zeolite mineralization from Soutěsky near Děčín \\ (Czech Republic)
}

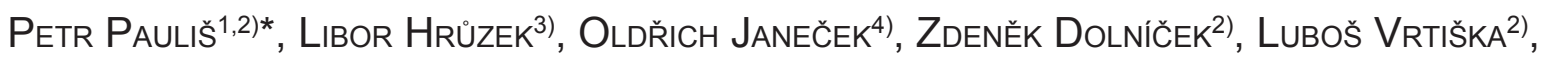 \\ Radana Malíkováe ${ }^{2)}$, OndŘej Pour ${ }^{5)}$ a Ferry Fediuk ${ }^{6)}$ \\ 1)Smíškova 564, 28401 Kutná Hora; *e-mail petr.paulis@post.cz \\ ${ }^{2)}$ Mineralogicko-petrologické oddělení, Národní muzeum, Cirkusová 1740, 19300 Praha 9 - Horní Počernice \\ 3)Pobřežní 1016, 47114 Kamenický Šenov \\ 4)Albrechtická 613, 43401 Most \\ 5)Česká geologická služba, Geologická 6, 15200 Praha 5 \\ 6) Na Petřinách 1897, 16200 Praha 6
}

Pauliš P, Hrưzek L, Janeček O, Dolníček Z, VRtiška L, Malíková R, Pour O, Fediuk F (2021) Böhmit a doprovodná zeolitová mineralizace ze Soutěsek u Děčína (Česká republika). Bull Mineral Petrolog 29(1): 164-177 ISSN $2570-7337$

\begin{abstract}
A new locality of böhmite and zeolite minerals, called „Soutěsky above the quarry“, occurs near the quarry „Soutěsky“ on the SW slope of the Hlídka hill, eastward of the Soutěsky village, about $5 \mathrm{~km} \mathrm{SW}$ od the town of Děčín (Czech Republic). The mineralization is bound to vugs of Cenozoic volcanics. Böhmite forms mostly whitish to brownish hemispherical to spherical clusters up to $5 \mathrm{~mm}$ in size. The unit-cell parameters of böhmite, refined from the X-ray powder data, are a 2.871 (3), b 12.216(9), c 3.699(4) $\AA$ and $V$ 129.7(2) $\AA^{3}$. Chemical analyses correspond to the empirical formula $\left(\mathrm{Al}_{0.92} \mathrm{Si}_{0.06}\right)_{\Sigma 0.98} \mathrm{O}(\mathrm{OH})$. The following zeolites have been found in association with böhmite: thomsonite-Ca, phillipsite- $\mathrm{K}$, gismondine, chabazite-Ca and analcime, as well as calcite. Minerals crystallized in following succession: calcite I $\rightarrow$ phillipsite-K $\rightarrow$ böhmite $\rightarrow$ calcite II $\rightarrow$ thomsonite-Ca $\rightarrow$ gismondine $\rightarrow$ calcite III. Independently, (older) analcime and (younger) chabazite-Ca occur. These minerals probably crystallized from low tempered solutions, enriched in Al ions and alkalies, the source of which can be found in altered rock-forming alumosilicates (analcime, nepheline).
\end{abstract}

Key words: böhmite, thomsonite-Ca, phillipsite-K, gismondine, chabazite-Ca, analcime, powder X-ray diffraction data, unit-cell parameters, chemical composition, Cenozoic volcanics, Soutěsky - nad lomem, Czech Republic

Obdrženo 6. 5. 2021; prijiato 30. 6. 2021

\section{Úvod}

Lokalita nazvaná autory Soutěsky - nad lomem se nachází nedaleko známé zeolitové lokality Soutěsky - lom, na jihozápadním svahu vrchu Hlídka, v. od Soutěsek, cca $5 \mathrm{~km}$ jz. od Děčína. Tento rozsáhlý a členitý vulkanický vrch o plošných rozměrech cca $3.6 \times 2.5 \mathrm{~km}$ je na jihu a západě omezen tokem řeky Ploučnice, na severu Dobrnským potokem a na východě silnicí Dobrná - Ovesná Benešov n. Ploučnicí (obr. 1). Morfologicky nejvýraznějším prvkem vrchu je jeho strmý, asi 300 m vysoký jižní a západní svah se dvěma dílčími vrcholy poblíž hrany svahu, Hlídkou (dřive Hutberg, 480 m n. m.) na západě a bezejmennou kótou $474 \mathrm{~m}$ na jihovýchodě. Vrcholová plochá část široká 300 až 400 m s políčky, pastvinami a četnými remízky je protažená ve směru SZ - JV, s výběžkem na severovýchodě. Na východ vrch pokračuje pozvolným svahem do mělkého sedla, kterým vede silnice. Jižní a západní svah je zalesněný, v jeho vyšší a strmější polovině je řada výchozů a skalek vulkanických hornin, z nichž nejznámější jsou Havraní kameny nad Jedlkou. Spodní, pozvolnější polovina svahu, je tvořena mocným svahovým sut'ovým materiálem. Vlastní naleziště (GPS: $50^{\circ} 45^{\prime 2} 2.8^{\prime \prime} \mathrm{N}$; $\left.14^{\circ} 16^{\prime} 7.8^{\prime \prime} \mathrm{E}\right)$ se nachází na katastru obce Soutěsky (část obce Malá Veleň), asi $500 \mathrm{~m}$ severně od horní hrany stávajícího kamenolomu (obr. 2). Na lokalitu vede od silnice podél lomu nezřetelná lesní cesta. Lokalita se nachází poblíž rozcestí, z něhož jedna cesta vede po vrstevnici na sever k vrchu Hlídka a druhá se klikatí na východ $\mathrm{k}$ bezejmenné kótě $474 \mathrm{~m} \mathrm{n}$. m. Asi $100 \mathrm{~m}$ jv. je po spádnici orientovaná rozsáhlá hromada vysbíraného kamení. Většina studovaných vzorků minerálů s böhmitem a zeolitovou mineralizací pochází z bloků vulkanitů nacházejících se volně na povrchu (obr. 3). Jejich zdrojem byla patrně nedaleká nevýrazná skalka (obr. 4, 5) obsahující drobné dutiny s obdobnou mineralizací, ze které byl zřejmě odebírán materiál na údržbu cesty a stavbu náspu a ochranných zídek. $V$ jedné $z$ nich byly též nalezeny vzorky se zeolitovou mineralizací.

\section{Geologie a petrologie lokality}

Mateřskou horninou studované mineralizace je alterací postižená a četnými vesikulami prostoupená okrajová vulkanická facie, která je nositelem zvlášt' bohatého a pestrého zeolitové společenství. Na rozdíl od čerstvé 
čedičové horniny těžené kamenolomem, která má barvu tmavošedou až modravě černošedou, se vzorky z okrajové facie nad lomem vyznačuji barvou kalně tmavohnědou až šedohnědou. Navíc je pro ně př́iznačná prítomnost četných dutinek, zčásti poloprázdných, většinou však mandlovcovitě zaplněných bělavými minerály zeolitové skupiny. Tyto většinou nepravidelné dutiny o délce do $5 \mathrm{~cm}$, ale i pres $10 \mathrm{~cm}$, jsou zpravidla výrazně protáhlé a subparalelně orientované. Vlastní čedičová hmota, v níž jsou vesikuly víceméně pravidelně rozmístěny, je velmi jemnozrnná, s minerálními součástkami značně pod makroskopickou rozeznatelností. Zatímco makroskopicky nejsou vyrostlice prakticky viditelné, ve výbruse je porfyrická stavba horniny patrná zřetelně. Vyrostlice o celkovém podílu cca $15 \%$ jsou výhradně zastoupeny prismatickým, hypautomorfně až automorfně omezeným klinopyroxenem nafialovělé barvy, místy se zonální strukturou. Velikost těchto vyrostlic kolísá v dolních desetinách $\mathrm{mm}$. Základní hmota se skládá z izometricky zrnitého klinopyroxenu, xenomorfně zrnitého analcimu, malého množství mikrolištovitého plagioklasu a rudních (magnetitových, zčásti alterovaných) zrn. Velikost minerálních zrn v základní hmotě kolísá kolem $0.01 \mathrm{~mm}$. Vulkanické sklo nebylo pozorováno, jeho prítomnost $\checkmark$ malém množství však nelze zcela vyloučit. Struktura horniny je drobně porfyrická $s$ mikrokrystalickou strukturou základní hmoty, textura je mírně proudovitě uspořádaná. $\mathrm{Na}$ základě mikroskopického popisu lze horninu označit jako analcimit s mírnou afinitou k analcimickému tefritu.
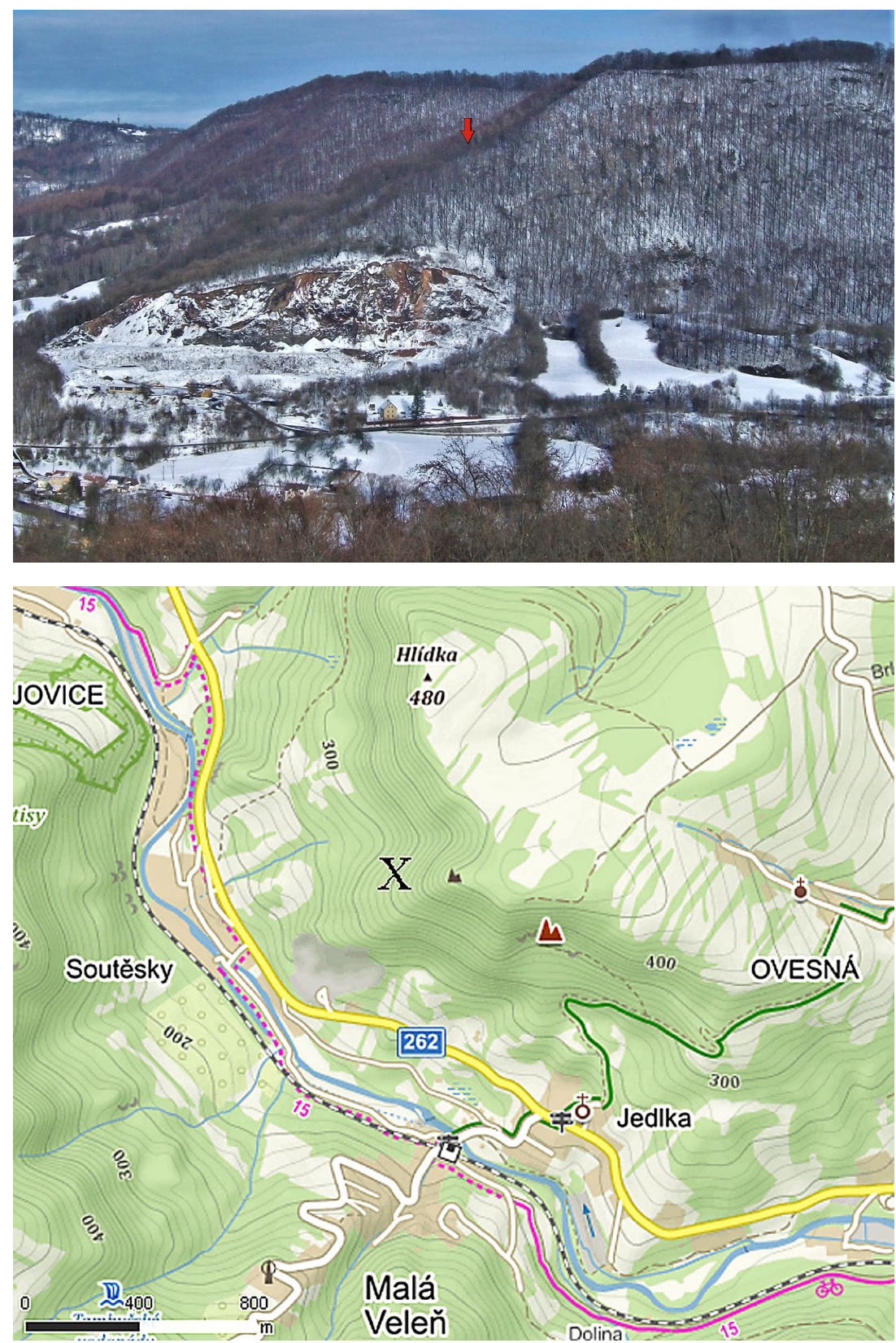

Obr. 1 Hřbet s vrcholovou kótou Hlídka s kamenolomem Soutěsky. Lokalita Soutěsky - nad lomem je označena šipkou, foto P. Zeman.

Obr. 2 Plánek lokality Soutěsky - nad lomem (lokalita označena $X$ ). Podle www.mapy.cz.

Obr. 3 Stará cesta, v jejímž okolí se vyskytuji bazaltoidni vulkanity $s$ popisovanou mineralizací. Foto P. Pauliš (2020).

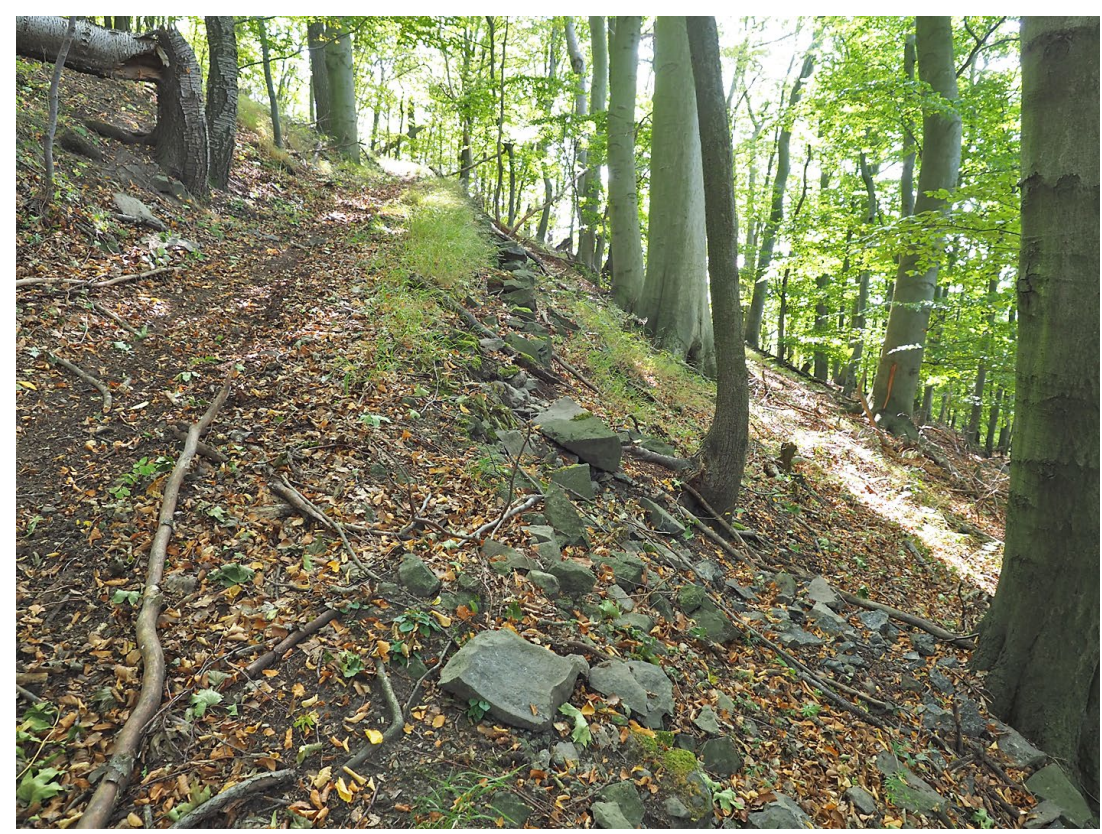



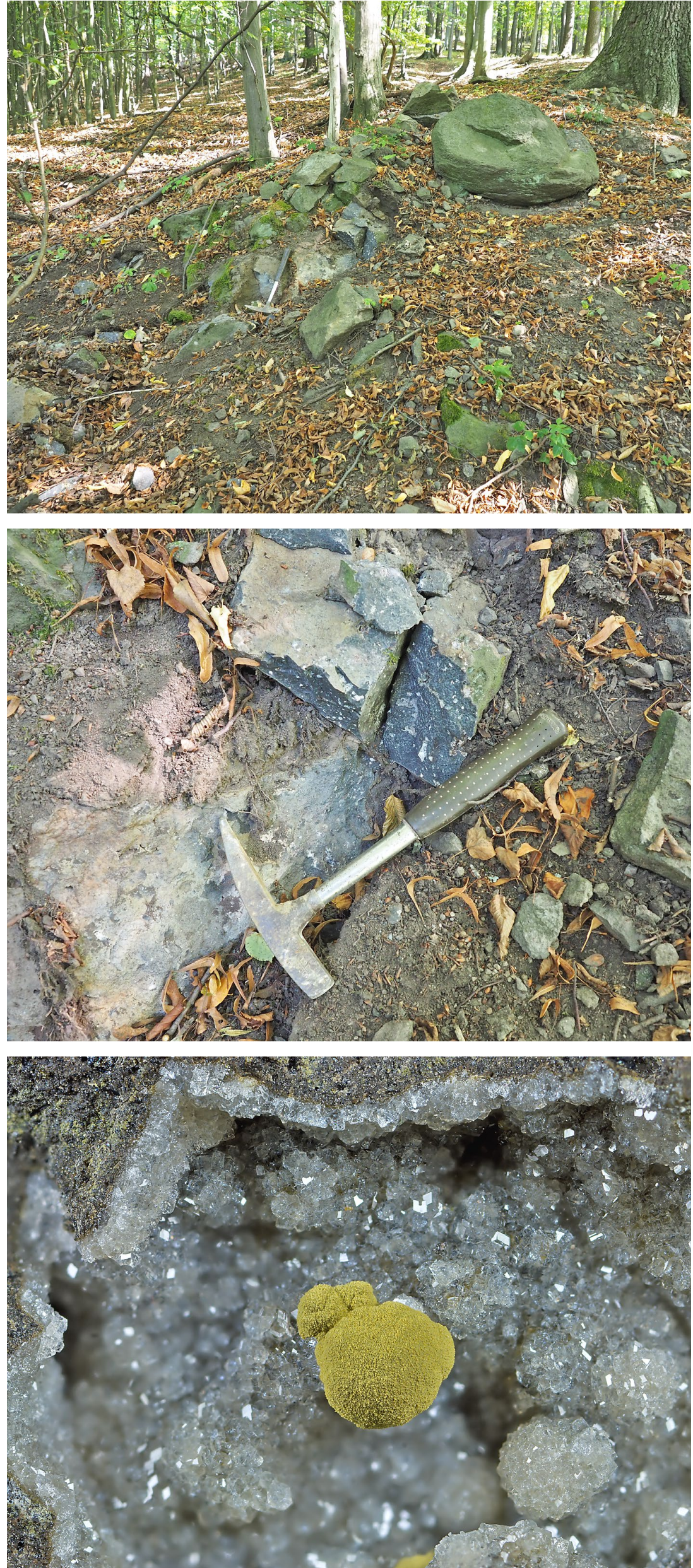

Zatímco bazaltoidní hornina z lomu je označována jako analcimický bazanit (Kužvart ed. 1983), tedy bazaltoidní hornina s olivínem, ve zkoumané okrajové facii olivín zjištěn nebyl.

\section{Metodika výzkumu}

Rentgenová prášková difrakční data byla získána pomocí práškového difraktometru Bruker D8 Advance (Národní muzeum, Praha) s polovodičovým pozičně citlivým detektorem LynxEye za užití CuKa záření (40kV, $40 \mathrm{~mA}$ ). Práškové preparáty byly naneseny $v$ acetonové suspenzi na nosič zhotovený z monokrystalu křemíku a následně pak byla pořízena difrakční data ve step-scanning režimu (krok $0.01^{\circ}$, načítací čas $8 \mathrm{~s} / \mathrm{krok}$ detektoru, celkový čas experimentu cca 15 hodin). Pozice jednotlivých difrakčních maxim byly popsány profilovou funkcí Pseudo-Voigt a upřesněny profilovým fitováním v programu HighScore Plus. Mř́žkové parametry byly zpřesněny metodou nejmenších čtverců pomocí programu Celref (Laugier, Bochu 2011).

Chemické složení minerálů bylo kvantitativně studováno pomocí elektronového mikroanalyzátoru Cameca SX100 (Národní muzeum, Praha, analytik Z. Dolníček) za podmínek: vinově disperzní analýza, napětí 15 $\mathrm{kV}$, proud $5 \mathrm{nA}$, průměr svazku $5 \mu \mathrm{m}$. Měřeny byly $\mathrm{Al}, \mathrm{Ba}, \mathrm{Ca}, \mathrm{Cl}, \mathrm{F}, \mathrm{Fe}, \mathrm{K}$, $\mathrm{Mg}, \mathrm{Mn}, \mathrm{N}, \mathrm{Na}, \mathrm{P}, \mathrm{Pb}, \mathrm{Rb}, \mathrm{S}, \mathrm{Si}, \mathrm{Sr}$ a Zn. Při analýzách byly využity následující standardy a analytické čáry: baryt $(\mathrm{Ba} L \alpha)$, albit $(\mathrm{NaK} \alpha)$, sanidin $(\mathrm{AlK} \alpha, \mathrm{Si} K \alpha, \mathrm{KK} \alpha)$, rodonit $(\mathrm{MnK} \alpha)$, diopsid $(\mathrm{MgK} \alpha), \mathrm{TiO}_{2}(\mathrm{TiK} \alpha)$, apatit $(\mathrm{PK} \alpha)$, halit $(\mathrm{Cl} K \alpha)$, hematit $(\mathrm{FeK} \alpha)$, $\mathrm{ZnO}(\mathrm{ZnK} \alpha)$, celestin $(\mathrm{S} K \alpha, \operatorname{Sr} L \beta)$,

Obr. 4 Soutěsky - nad lomem, nevelký výchoz vulkanitů s popisovanou mineralizací. Foto P. Pauliš (2020).

Obr. 5 Dutinatý vulkanit s popisovanou mineralizací. Foto P. Pauliš (2020).

Obr. 6 Böhmit narůstající na phillipsit-K, lokalita Soutěsky - nad lomem. Šírka záběru $9.8 \mathrm{~mm}$, foto $B$. Bureš. 
vanadinit $(\mathrm{P} K \alpha)$, BN $(\mathrm{N} K \alpha)$, wollastonit $(\mathrm{CaK \alpha}), \mathrm{ZnO}(\mathrm{ZnK \alpha})$ a $\mathrm{LiF}(\mathrm{FK} \alpha)$. Získaná data byla přepočítána na hm. \% oxidů za použití algoritmu PAP (Pouchou, Pichoir 1985). Obsahy měřených prvků, které nejsou uvedeny $v$ níže prezentovaných tabulkách minerálních analýz, byly ve všech prípadech pod mezí stanovitelnosti, která se pohybovala nejčastěji mezi $0.05-0.1$ hm. \%.

Ramanovo spektrum böhmitu bylo pořízeno za pomoci disperzního spektrometru DXR (Thermo Scientific) spojeného $s$ konfokálním mikroskopem Olympus (Národní muzeum Praha). Podmínky měření: zvětšení objektivu 20x, použitý laser $633 \mathrm{~nm}$, rozsah měření $45-1200 \mathrm{~cm}^{-1}$, doba expozice $1800 \mathrm{~s}$, výkon laseru $4 \mathrm{~mW}$, apertura $50 \mu \mathrm{m}$ pinhole, velikost měřené stopy $1.6 \mu \mathrm{m}$. Vizuální kontrolou povrchu po měření a sledováním případných změn spektra $v$ průběhu měření nebylo zjištěno termické poškození měřených bodů. Spektrometr byl kalibrován pomocí softwarově řízené procedury s využitím emisních linií neonu (kalibrace vinočtu), Ramanových pásů polystyrenu (kalibrace frekvence laseru) a standardizovaného zdroje bílého světla (kalibrace intenzity). Získaná spektra byla zpracována pomocí programu Omnic 9 (Thermo Scientific).

\section{Popis mineralizace}

Výskyt zeolitové mineralizace na lokalitě Soutěsky - nad lomem objevil v roce 1993 třetí z autorů tohoto příspěvku (OJ). Poměrně hojný böhmit byl identifikován až v rámci revize lokality v roce 2020

Obr. 7 Böhmit narůstající na phillipsit-K, lokalita Soutěsky - nad lomem. Šírka záběru10 mm, foto B. Bureš.

Obr. 8 Typická ukázka nárůstu krystalů thomsonitu-Ca na böhmit, lokalita Soutěsky - nad lomem. Šírka záběru $7 \mathrm{~mm}$, foto $B$. Bureš.

Obr. 9 Průřez kulovitým agregátem böhmitu, světlejší vnitřní část obsahuje menši príměs $\mathrm{SiO}_{2}$ a je méně hydratovaná než tmavší lem, tenká obruba je tvořena opálem. Šírka záběru $1.3 \mathrm{~mm}$, BSE foto Z. Dolníček.
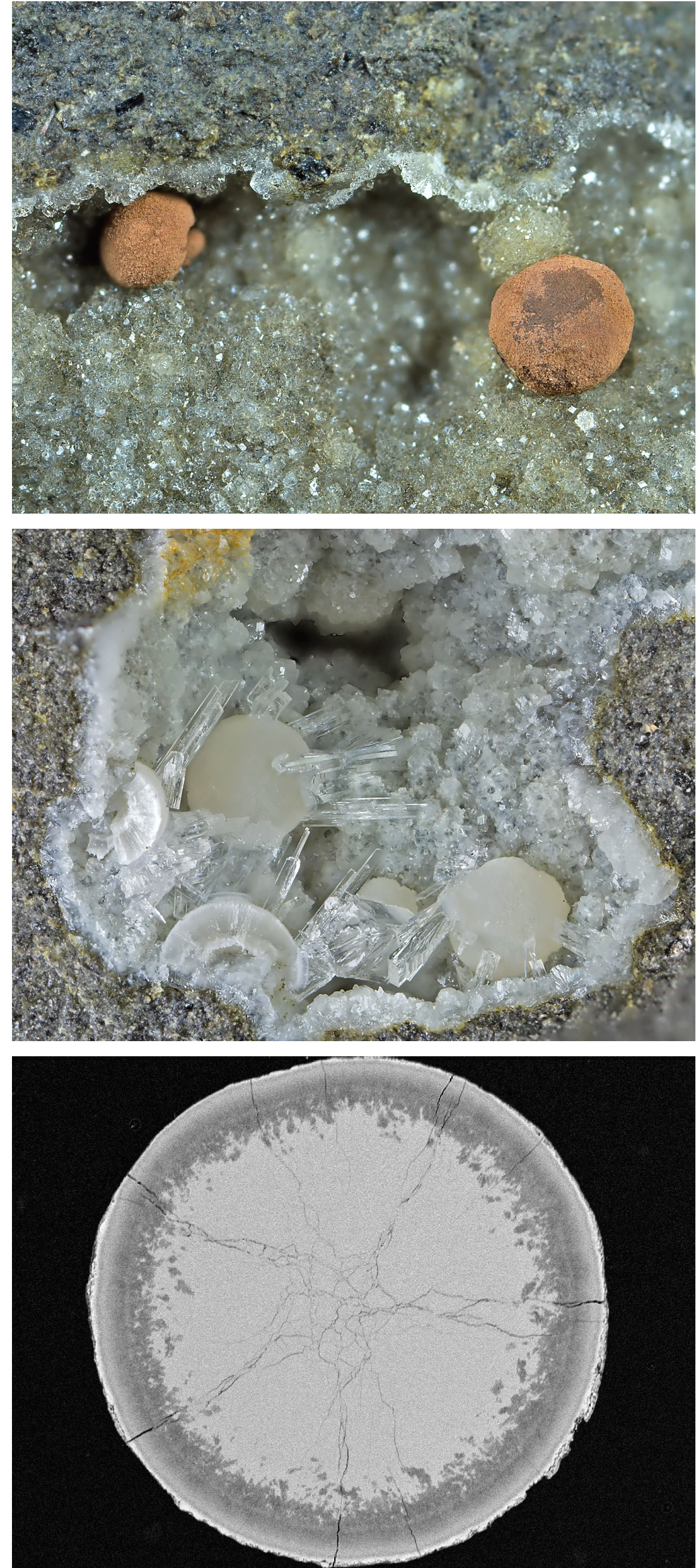
Tabulka 1 Rentgenová prášková data böhmitu ze Soutěsek

\begin{tabular}{cccccccccccc}
\hline$h$ & $k$ & $l$ & $d_{o b s}$ & $l_{o b s}$ & $d_{c a l c}$ & $h$ & $k$ & $l$ & $d_{o b s}$ & $l_{\text {obs }}$ & $d_{\text {calc }}$ \\
\hline 0 & 2 & 0 & 6.075 & 100 & 6.108 & 0 & 2 & 2 & 1.7712 & 5 & 1.7701 \\
0 & 2 & 1 & 3.159 & 36 & 3.164 & 1 & 5 & 1 & 1.6608 & 4 & 1.6622 \\
1 & 3 & 0 & 2.3431 & 18 & 2.3466 & 0 & 8 & 0 & 1.5268 & 5 & 1.5270 \\
0 & 6 & 0 & 2.0454 & 1 & 2.0360 & 1 & 3 & 2 & 1.4546 & 1 & 1.4525 \\
1 & 3 & 1 & 1.9803 & 1 & 1.9815 & 2 & 0 & 0 & 1.4363 & 4 & 1.4357 \\
1 & 5 & 0 & 1.8612 & 18 & 1.8607 & 1 & 7 & 1 & 1.3817 & 4 & 1.3831 \\
0 & 0 & 2 & 1.8499 & 31 & 1.8495 & 0 & 6 & 2 & 1.3673 & 1 & 1.3690 \\
\hline
\end{tabular}

Tabulka 2 Parametry základní cely böhmitu (pro ortorombickou prostorovou grupu $\mathrm{Cmcm}$ )

\begin{tabular}{rccc}
\hline & tato práce & Bokhimi et al. (2001) & Pauliš et al. (2015a) \\
\hline$a[\AA]$ & $2.871(3)$ & $2.8678(1)$ & $2.869(1)$ \\
$b[\AA]$ & $12.216(9)$ & $12.2188(4)$ & $12.218(6)$ \\
$c[\AA]$ & $3.699(4)$ & $3.6941(4)$ & $3.699(2)$ \\
$V\left[\AA^{3}\right]$ & $129.7(2)$ & 129.45 & $129.7(1)$ \\
\hline
\end{tabular}

Tabulka 3 Chemické složení böhmitu ze Soutěsek (hm. \%)

\begin{tabular}{lrrrr}
\hline & mean & 1 & 2 & 3 \\
\hline $\mathrm{SiO}_{2}$ & 2.90 & 3.52 & 1.95 & 2.87 \\
$\mathrm{Al}_{2} \mathrm{O}_{3}$ & 73.87 & 74.98 & 74.17 & 72.46 \\
$\mathrm{MgO}$ & 0.40 & 0.50 & 0.25 & 0.45 \\
$\mathrm{CaO}$ & 0.38 & 0.43 & 0.33 & 0.39 \\
$\mathrm{H}_{2} \mathrm{O}$ & 14.22 & 14.67 & 14.28 & 13.99 \\
\hline total & 91.77 & 94.10 & 90.98 & 90.16 \\
\hline $\mathrm{Si}^{4+}$ & 0.061 & 0.073 & 0.042 & 0.062 \\
$\mathrm{Al}^{3+}$ & 0.918 & 0.903 & 0.942 & 0.915 \\
$\mathrm{Mg}^{2+}$ & 0.012 & 0.015 & 0.008 & 0.014 \\
$\mathrm{Ca}^{2+}$ & 0.009 & 0.009 & 0.008 & 0.009 \\
$\mathrm{H}^{+}$ & 1.000 & 1.000 & 1.000 & 1.000 \\
\hline$\Sigma \mathrm{Si}+\mathrm{Al}+\mathrm{Mg}+\mathrm{Ca}$ & 1.000 & 1.000 & 1.000 & 1.000 \\
\hline
\end{tabular}

Koeficienty empirických vzorců počítány na bázi Si+Al+Mg+Ca = 1 apfu. Obsahy $\mathrm{H}_{2} \mathrm{O}$ dopočteny na bázi ideálního vzorce.

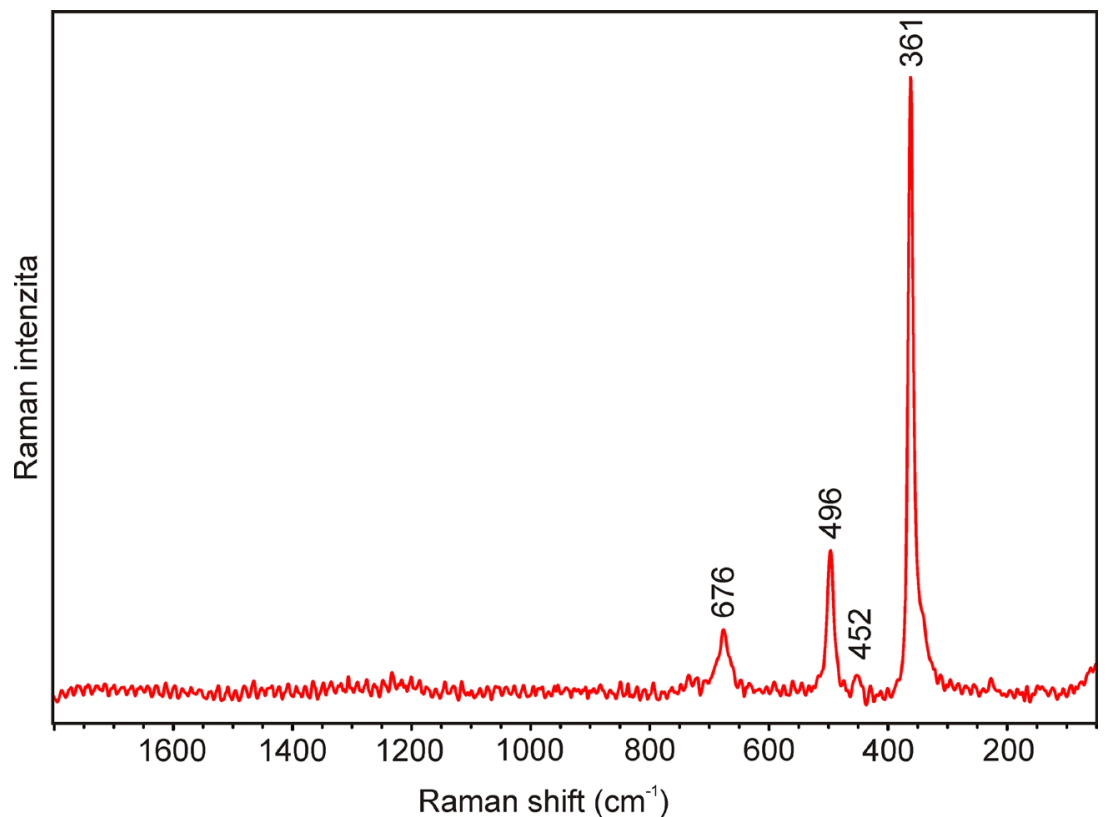

Obr. 10 Ramanovo spektrum böhmitu ze Soutěsek.
Böhmit, ortorombický $\mathrm{AlO}(\mathrm{OH})$, je patrně nejzajímavějším minerálem popisované asociace. Vytvárí v dutinách charakteristické polokulovité, kulovité a méně často i snopkovité agregáty s radiálně paprsčitou stavbou. Velikost agregátů dosahuje běžně 1 až $2 \mathrm{~mm}$, vzácněji až $5 \mathrm{~mm}$ (obr. 6). Jen malá část agregátů má vnitřní stavbu strukturně i barevně homogenní, u některých je patrná barevná zonálnost. Část agregátů má stavbu výrazně slupkovitou - jsou evidentně složeny z několika koncentrických vrstviček odlišné barvy, ostře oddělených tenoučkou vrstvičkou jiného minerálu. Některé vrstvy obsahuji jemně zrnitý kalcit a mohou být zčásti vyloužené. Zjištěny byly i duté útvary tvořené tenkou perimorfózou jílovité nebo železité hmoty, místy druhotně vyplněné thomsonitem-Ca. Barva vrstev böhmitu je nejčastěji bělavá, krémová, žlutavá, nahnědlá či nazelenalá. Povrch agregátů bývá jen vzácně čistý, hladký a bělavý, mnohem častěji je zrnitý, drsný až hrubý, špinavě bílý, krémový, medový, zelenavý i hnědočervený. Agregáty jsou často pokryty produkty zvětrávání, železitými a jílovými hmotami (obr. 7). Někdy je radiálně paprsčitá stavba málo výrazná, agregát je až celistvý.

Böhmit $v$ dutinách nasedá na phillipsit-K a je porostlý thomsonitem -Ca (obr. 8) a gismondinem. Kuličky böhmitu jsou často základem kulovitých agregátů thomsonitu-Ca.

Rentgenová prášková data böhmitu ze Soutěsek (tab. 1) jsou blízká datům pro tento minerální druh, jeho zpřesněné parametry dobře odpovídají publikovaným údajům (tab. 2). V BSE obraze se u studovaných vzorků projevuje výrazná chemická zonalita (obr. 9). Vnější zóna sférických agregátů je více hydratovaná a oproti centrální části (cca $2 \mathrm{hm}$. \%) má vyšší príměs $\mathrm{SiO}_{2}$ (cca $3.5 \mathrm{hm}$. $\%)$. Povrch agregátů často povléká tenká vrstva tvořená $\mathrm{SiO}_{2}$ (opál?). Kromě Si (až 0.073 apfu) byly zjištěny minoritní obsahy $\mathrm{Mg}(0.008$ $0.015 \mathrm{apfu}$ ) a Ca (0.009 apfu); ostatní měřené prvky jsou pod mezí detekce (tab. 3). Empirický vzorec (průměr tří bodových analýz) na bázi $\mathrm{Si}+\mathrm{Al}+\mathrm{M}$ $\mathrm{g}+\mathrm{Ca}=1$ apfu je možno vyjádřit jako $\left(\mathrm{Al}_{0.92} \mathrm{Si}_{0.06}\right)_{\Sigma 0.98} \mathrm{O}(\mathrm{OH})$. Ramanovo spektrum (obr. 10) je identické s referenčním spektrem böhmitu. 
Thomsonit-Ca je na lokalitě minerálem poměrně běžným, Ize ho nalézt i $v$ největších dutinách. Nasedá na phillipsit-K a böhmit (obr. 11 - 14), porůstá jej gismondin. Vytváří dokonale vyvinuté, tlustě tabulkovité i sloupečkové, bezbarvé, často dokonale čiré, skelně lesklé krystaly ukončené plochou báze. Délka krystalů se pohybuje obvykle mezi 1 až $2 \mathrm{~mm}$, vzácněji dosahuje až $4 \mathrm{~mm}$. Thomsonit-Ca často vytvárí polokulovité až kulovité útvary o průměru do $8 \mathrm{~mm}$. Agregáty mají charakteristický povrch tvořený tabulkami různé délky, ukončenými bází. Agregáty jsou prítomné $v$ dutinách většinou jednotlivě, ale mohou tvořit i souvislou plochu s ledvinitým povrchem. Další formou výskytu jsou jednotlivé, pěkně vyvinuté tabulky a jejich nahodilé srostlice většinou až $2 \mathrm{~mm}$ velké a též svazečkovité a jemně štětičkovité agregáty (obr. 15), vzácně i křižové prorostlice. Zajímavé jsou vzorky, kdy na agregátu böhmitu narůstá jediný, dokonale vyvinutý sloupečkovitý krystal thomsonitu-Ca. Thomsonit-Ca často vyplňuje prázdné prostory $\checkmark$ agregátech böhmitu, někdy $v$ podobě zrnitého agregátu, většinou jen jednotlivými prorůstajícími sloupečky.

Rentgenová prášková data thomsonitu-Ca ze Soutěsek (tab. 4) jsou blízká datům pro tento minerální druh, zpřesněné parametry dobře odpovídají publikovaným údajům pro tento zeolit (tab. 5). V BSE obraze je studovaný minerál homogenní. Chemickou analýzou byly zjištěny obsahy $\mathrm{Si}, \mathrm{Al}, \mathrm{Ca}, \mathrm{Sr}$ a Na; ostatní měřené prvky jsou pod mezi detekce (tab. 6). Empirický vzorec thomsonitu-Ca (průměr šesti bodových analýz) je na bázi 20 atomů kyslíku možno vyjádřit
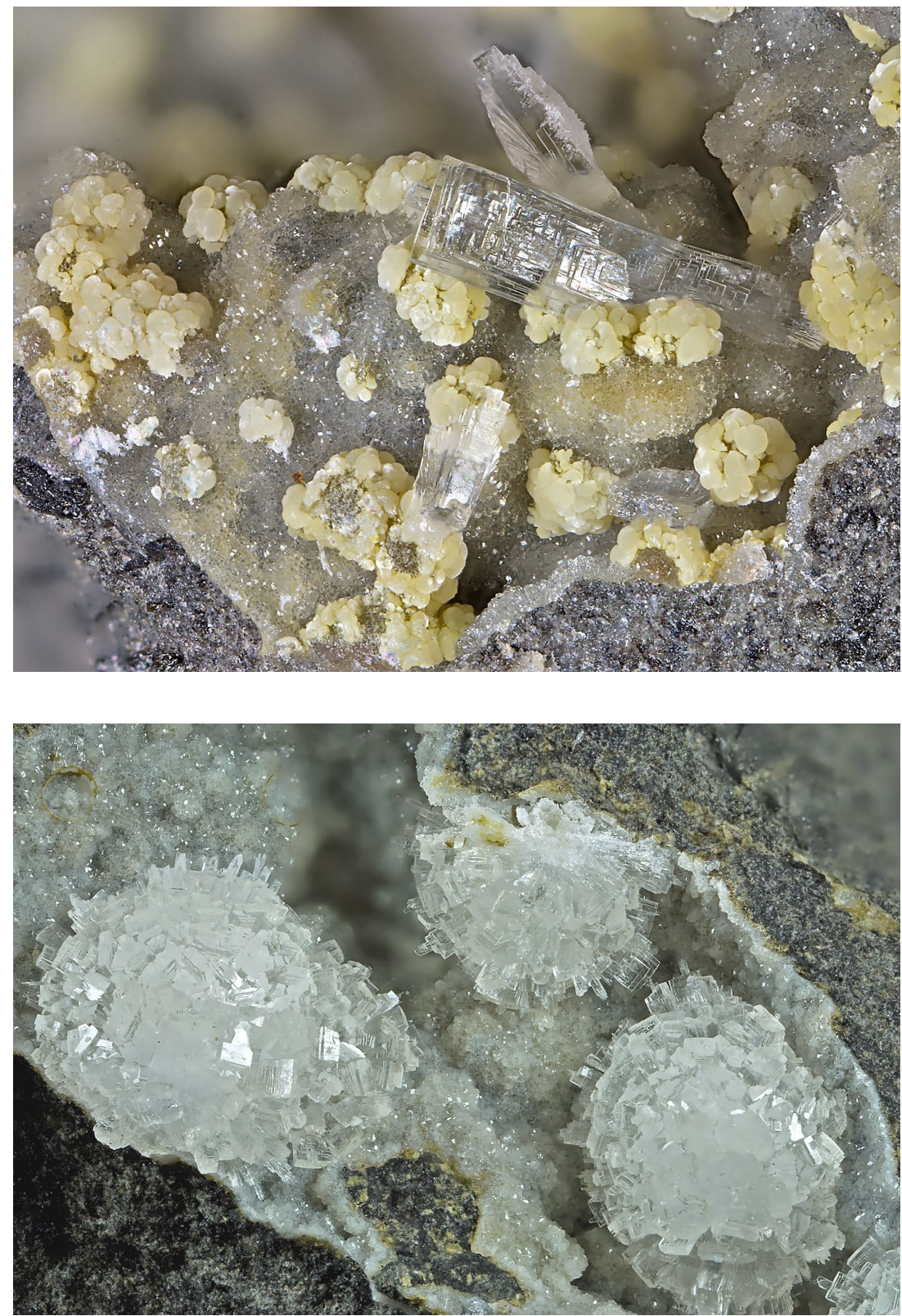

Obr. 11 Thomsonit-Ca narůstající na böhmit a phillipsit-K, lokalita Soutěsky - nad lomem. Šírka záběru $5.8 \mathrm{~mm}$, foto $B$. Bureš.

Obr. 12 Thomsonit-Ca, lokalita Soutěsky - nad lomem. Šiřka záběru $20 \mathrm{~mm}$, foto $B$. Bureš.

Obr. 13 Thomsonit-Ca, lokalita Soutěsky - nad lomem. Šířka záběru $6.8 \mathrm{~mm}$, foto $B$. Bureš.

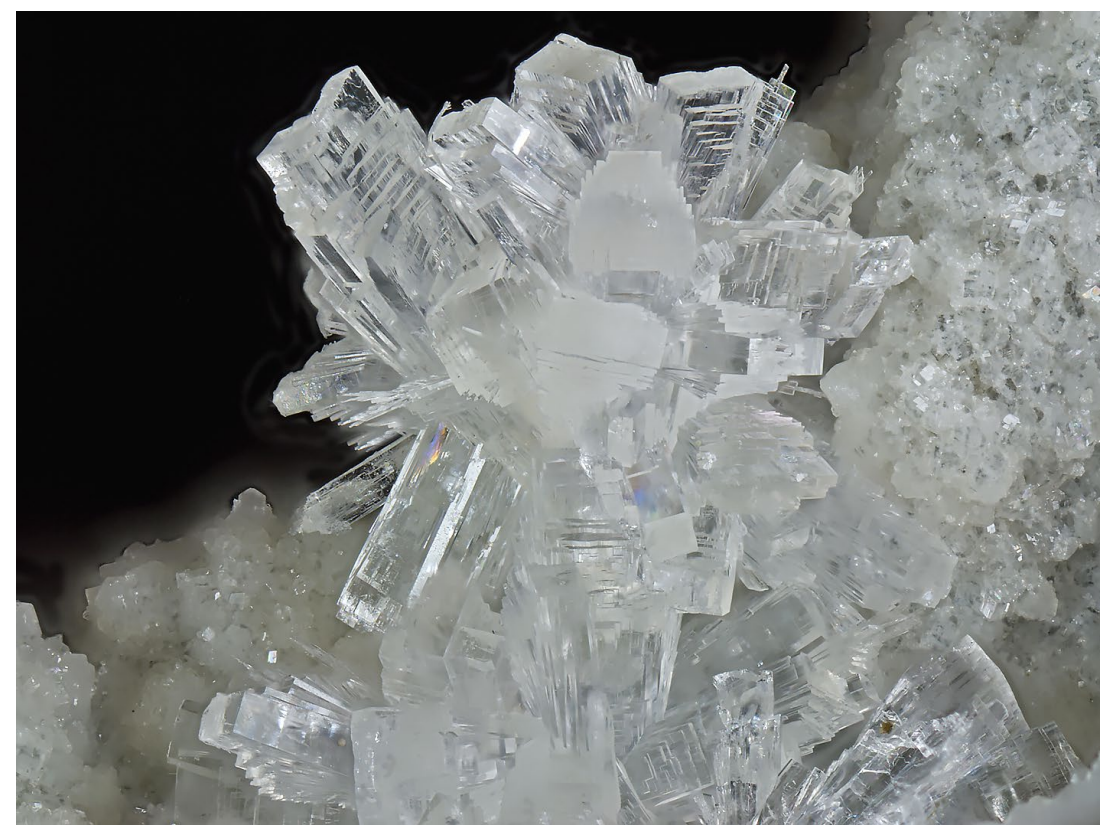


jako $\left(\mathrm{Ca}_{1.69} \mathrm{Sr}_{0.13}\right)_{\Sigma 1.82}\left(\mathrm{Al}_{4.84} \mathrm{Si}_{5.17} \mathrm{O}_{20}\right) \cdot 6 \mathrm{H}_{2} \mathrm{O}$. Zvýšené hodnoty stroncia (max. $2.28 \mathrm{hm}$. \% SrO; 0.183 apfu Sr) nejsou u thomsonitu-Ca v ČR velkou vzácností, například z Tachovského vrchu u Doks je uváděn obsah až 4.5 hmot. \% SrO (Pauliš et al. 2017) a z Babětína u Těchlovic až 4.7 hm. \% SrO (Pauliš et al. 2018a). Hodnota $\mathrm{T}_{\mathrm{Si}}=\mathrm{Si} /(\mathrm{Si}+\mathrm{Al})$ $=0.52$ thomsonitu-Ca ze Soutěsek je ve spodní části rozmezí publikovaného Coombsem et al. (1997).

Phillipsit-K je nejstarším a nejhojnějším zeolitem na lokalitě. $V$ dutinách je většinou minerálem jediným. Vytvárí v nich souvislou výstelku velmi drobných (pod $0.5 \mathrm{~mm}$ ), izometrických, bezbarvých až bělavých, skelně lesklých krystalů (např. obr. 6 a 11). Na jiných lokalitách běžné sloupečkové krystaly zde zjištěny nebyly. Povrch krystalů je často povlečen špinavě bílými nerozpustnými produkty zvětrávání. Na phillipsit-K narůstají ostatní minerály.

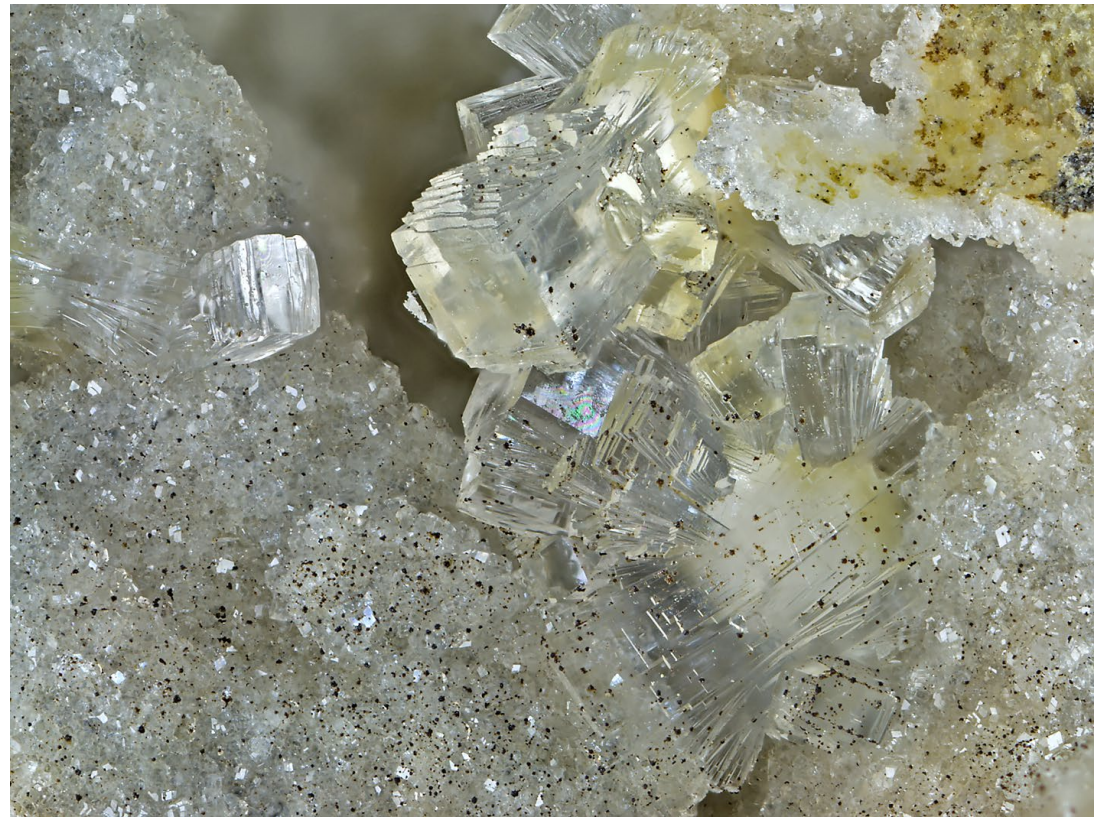

Obr. 14 Základem většiny srostlic thomsonitu-Ca jsou kulovité agregáty böhmitu, lokalita Soutěsky - nad lomem. Šiřka záběru $6 \mathrm{~mm}$, foto B. Bureš.

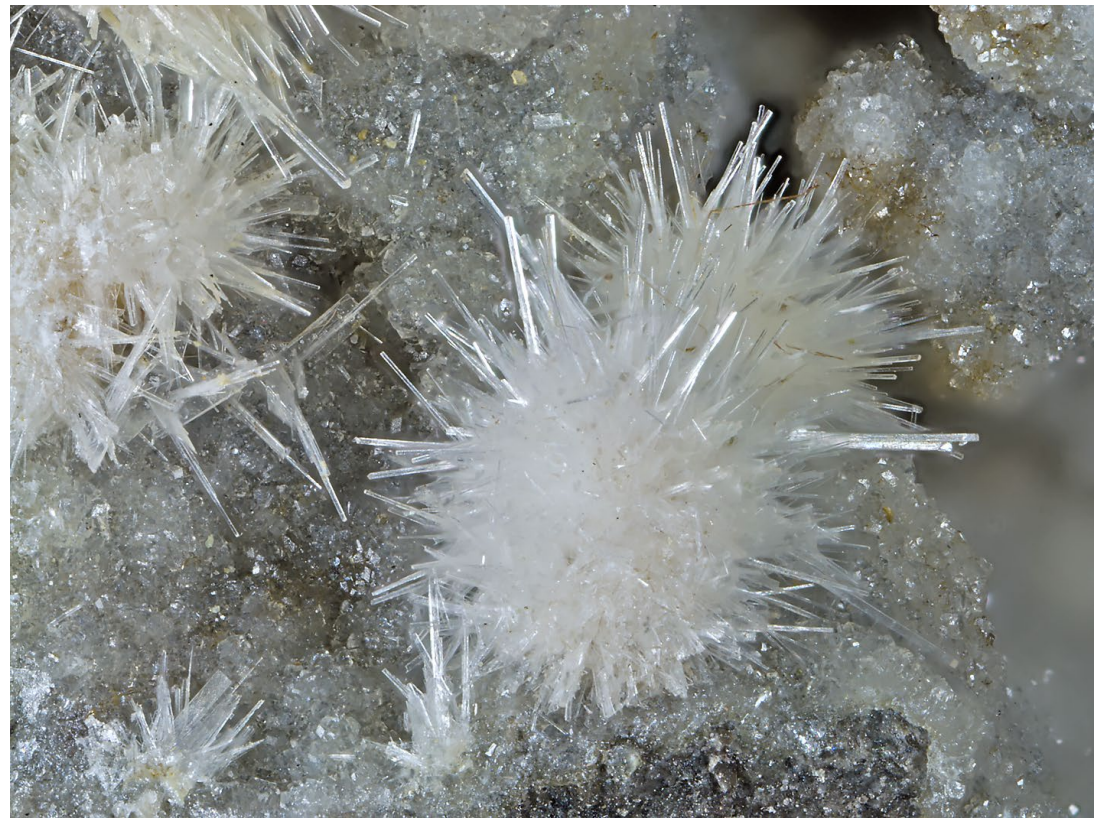

Obr. 15 Tenké jehlicovité krystaly thomsonitu-Ca, lokalita Soutěsky - nad lomem. Šírka záběru $6 \mathrm{~mm}$, foto B. Bureš.
Rentgenová prášková data (tab. 7) a zpřesněné mřížkové parametry (tab. 8) phillipsitu-K ze Soutěsek dobře odpovídají publikovaným údajům. V BSE obraze je phillipsit-K chemicky poměrně homogenní. Při studiu jeho chemického složení byly zjištěny obsahy $\mathrm{Si}, \mathrm{Al}, \mathrm{Ca}, \mathrm{Ba}$, $\mathrm{Na}$ a K; ostatní měřené prvky jsou pod mezí detekce (tab. 9). Empirický vzorec (průměr šesti bodových analýz) je na bázi 32 atomů kyslíku možno vyjádřit jako $\left(\mathrm{K}_{222} \mathrm{Ca}_{174}\right.$ $\left.\mathrm{Na}_{0.38} \mathrm{Ba}_{0.01}\right)_{\Sigma 4.35}\left(\mathrm{Al}_{5.37} \mathrm{Si}_{10.44} \mathrm{O}_{32}\right) \cdot 12 \mathrm{H}_{2} \mathrm{O}$. Hodnota $\mathrm{T}_{\mathrm{Si}}=\mathrm{Si} /$ $(\mathrm{Si}+\mathrm{Al})=0.66 \mathrm{u}$ studovaného phillipsitu-K je ve střední části uváděného rozmezí (Coombs et al. 1997). Obsah $\mathrm{BaO}$ (harmotomová složka) je nízký (0.010 - 0.021 apfu $\mathrm{Ba})$.

Gismondin se v dutinách velkých 4 až $5 \mathrm{~cm}$ vyskytuje spolu s phillipsitem-K, thomsonitem-Ca a böhmitem (obr. 16 a 17), je však poměrně vzácný. Vytváŕí typické skelně lesklé, bezbarvé až dokonale čiré dipyramidální krystaly až $2 \mathrm{~mm}$ velké. Vzácně vytváří, podobně jako na lokalitě Dobrná („Dobranka“), křížové prorostlice. Nejčastěji se vyskytuje $v$ podobě nenápadných, velice drobných (kolem $0.1 \mathrm{~mm}$ ) krystalů pravděpodobně zákonitě narůstajících na phillipsit-K. Souvisle porůstá i pseudooktaedrické srostlice phillipsitu-K. Méně často vytváří v dutinách bohaté až souvislé výstelky z větších krystalů. $V$ dutinách může být jediným zeolitem (narostlý na kalcitové výstelce) nebo porůstá phillipsit-K a thomsonit-Ca.

Rentgenová prášková data studovaného gismondinu (tab. 10) jsou blízká datům pro tento minerální druh, jeho zpřesněné mřižkové parametry dobře odpovídají publikovaným údajům (tab. 11). V BSE obraze je studovaný minerál chemicky homogenní. Při studiu chemického složení (tab. 12) byly zjištěny obsahy $\mathrm{Si}, \mathrm{Al}, \mathrm{Ca}$ a $\mathrm{Na}$; ostatní měřené prvky jsou pod mezí detekce. Empirický vzorec (průměr pěti bodových analýz) na bázi 8 atomů kyslíku je možno vyjádřit jako $\left(\mathrm{Ca}_{0.96} \mathrm{Na}_{0.02}\right)_{\Sigma 0.98}\left(\mathrm{Al}_{1.94}\right.$ $\left.\mathrm{Si}_{206} \mathrm{O}_{8}\right) \cdot 4.5 \mathrm{H}_{2} \mathrm{O}$. Hodnota $\mathrm{T}_{\mathrm{Si}}=\mathrm{Si} /$ $(\mathrm{Si}+\mathrm{Al})=0.51$ se nachází na spodní hranici publikovaného rozmezí gismondinu (Coombs et al. 1997).

Chabazit-Ca byl spolu s analcimem zjištěn $v$ jediném kusu tmavě šedého, silně drobně bublinatého vulkanitu s obsahem hojných, až 3 $\mathrm{mm}$ velkých vyrostlic černého pyroxenu. Velikost oválných dutinek se souvislým povlakem jemnè krystalovaného phillipsitu- $K v$ této hornině obvykle nepřesahuje $8 \mathrm{~mm}$. V největších dutinkách (do $2 \mathrm{~cm}$ délky) tvoři chabazit bezbarvá, skelně lesklá penetrační dvojčata (fakolity) až 7 $\mathrm{mm}$ velká.

Rentgenová prášková data chabazitu-Ca ze Soutěsek (tab. 13) jsou blízká datům pro tento minerál- 
Tabulka 4 Rentgenová prášková data thomsonitu-Ca ze Soutěsek

\begin{tabular}{|c|c|c|c|c|c|c|c|c|c|c|c|c|c|c|c|c|c|}
\hline$h$ & $k$ & I & $d_{o b s}$ & $I_{o b s}$ & $d_{\text {calc }}$ & $h$ & $k$ & $I$ & $d_{o b s}$ & $I_{o b s}$ & $d_{c a l c}$ & $h$ & $k$ & 1 & $d_{o b s}$ & $I_{o b s}$ & $d_{\text {calc }}$ \\
\hline 2 & 0 & 0 & 6.553 & 20 & 6.553 & 0 & 4 & 4 & 2.3178 & $<1$ & 2.3241 & 0 & 7 & 3 & 1.7172 & $<1$ & 1.7178 \\
\hline 1 & 0 & 2 & 5.906 & 4 & 5.910 & 5 & 2 & 2 & 2.2837 & 3 & 2.2831 & 3 & 7 & 0 & 1.7154 & 7 & 1.7150 \\
\hline 1 & 2 & 1 & 5.334 & 7 & 5.345 & 4 & 4 & 1 & 2.2762 & 2 & 2.2777 & 5 & 3 & 5 & 1.7133 & 9 & 1.7127 \\
\hline 2 & 2 & 0 & 4.623 & 35 & 4.624 & 0 & 5 & 3 & 2.2480 & 16 & 2.2471 & 4 & 6 & 3 & 1.6771 & 3 & 1.6766 \\
\hline 2 & 2 & 1 & 4.350 & 20 & 4.366 & 6 & 0 & 0 & 2.1847 & 12 & 2.1842 & 7 & 0 & 4 & 1.6294 & 4 & 1.6297 \\
\hline 0 & 1 & 3 & 4.174 & 2 & 4.182 & 1 & 0 & 6 & 2.1782 & 10 & 2.1766 & 5 & 6 & 2 & 1.6214 & 8 & 1.6230 \\
\hline 1 & 3 & 0 & 4.111 & 76 & 4.129 & 1 & 6 & 1 & 2.1187 & 9 & 2.1185 & 7 & 4 & 1 & 1.6120 & 16 & 1.6119 \\
\hline 2 & 2 & 2 & 3.768 & 3 & 3.791 & 1 & 6 & 2 & 2.0432 & 3 & 2.0416 & 3 & 7 & 3 & 1.5997 & $<1$ & 1.5986 \\
\hline 2 & 3 & 1 & 3.493 & 47 & 3.496 & 5 & 4 & 1 & 2.0201 & 1 & 2.0196 & 7 & 2 & 4 & 1.5822 & 7 & 1.5811 \\
\hline 4 & 0 & 0 & 3.268 & 15 & 3.276 & 5 & 3 & 3 & 2.0033 & 1 & 2.0012 & 6 & 3 & 5 & 1.5712 & 5 & 1.5714 \\
\hline 0 & 4 & 0 & 3.261 & 22 & 3.263 & 2 & 6 & 2 & 1.9718 & 1 & 1.9711 & 1 & 6 & 6 & 1.5390 & 1 & 1.5387 \\
\hline 2 & 2 & 3 & 3.193 & 9 & 3.193 & 2 & 4 & 5 & 1.9617 & $<1$ & 1.9622 & 3 & 4 & 7 & 1.5327 & 2 & 1.5327 \\
\hline 3 & 2 & 2 & 3.184 & 8 & 3.183 & 5 & 4 & 2 & 1.9531 & 2 & 1.9527 & 1 & 8 & 3 & 1.5202 & $<1$ & 1.5201 \\
\hline 4 & 1 & 1 & 3.094 & $<1$ & 3.090 & 3 & 1 & 6 & 1.9481 & 5 & 1.9480 & 3 & 2 & 8 & 1.5065 & 2 & 1.5062 \\
\hline 1 & 4 & 1 & 3.071 & 9 & 3.080 & 3 & 6 & 2 & 1.8690 & 2 & 1.8683 & 6 & 3 & 6 & 1.4621 & 14 & 1.4623 \\
\hline 4 & 0 & 2 & 2.939 & 21 & 2.937 & 5 & 3 & 4 & 1.8583 & $<1$ & 1.8582 & 6 & 6 & 3 & 1.4554 & 3 & 1.4552 \\
\hline 2 & 4 & 0 & 2.922 & 18 & 2.921 & 1 & 7 & 0 & 1.8458 & $<1$ & 1.8462 & 3 & 5 & 7 & 1.4453 & $<1$ & 1.4456 \\
\hline 4 & 2 & 1 & 2.858 & 13 & 2.859 & 6 & 0 & 4 & 1.8229 & 3 & 1.8232 & 5 & 7 & 3 & 1.4374 & 3 & 1.4367 \\
\hline 2 & 4 & 1 & 2.850 & 100 & 2.853 & 0 & 6 & 4 & 1.8192 & 3 & 1.8182 & 5 & 6 & 5 & 1.4147 & 1 & 1.4151 \\
\hline 2 & 3 & 3 & 2.801 & 1 & 2.801 & 4 & 6 & 0 & 1.8123 & 12 & 1.8124 & 7 & 2 & 6 & 1.3949 & 1 & 1.3948 \\
\hline 4 & 2 & 2 & 2.682 & 3 & 2.678 & 6 & 4 & 1 & 1.7971 & 3 & 1.7983 & 5 & 1 & 8 & 1.3918 & 1 & 1.3917 \\
\hline 2 & 4 & 2 & 2.668 & 80 & 2.673 & 7 & 2 & 1 & 1.7823 & 1 & 1.7832 & 1 & 3 & 9 & 1.3860 & 2 & 1.3861 \\
\hline 5 & 1 & 0 & 2.5707 & 10 & 2.5698 & 2 & 6 & 4 & 1.7521 & 2 & 1.7520 & 0 & 9 & 3 & 1.3786 & 1 & 1.3779 \\
\hline 1 & 5 & 0 & 2.5591 & 11 & 2.5603 & 4 & 6 & 2 & 1.7469 & 2 & 1.7481 & 5 & 8 & 2 & 1.3563 & 1 & 1.3558 \\
\hline 1 & 5 & 1 & 2.5161 & 1 & 2.5138 & 2 & 7 & 2 & 1.7329 & 3 & 1.7312 & 6 & 7 & 3 & 1.3504 & $<1$ & 1.3502 \\
\hline 2 & 3 & 4 & 2.4444 & 2 & 2.4446 & & & & & & & & & & & & \\
\hline
\end{tabular}

Tabulka 5 Parametry základní cely thomsonitu-Ca (pro ortorombickou prostorovou grupu Pncn)

\begin{tabular}{lllllll}
\hline & & $a[\AA]$ & $b[\AA]$ & $c[\AA]$ & $V\left[\AA^{3}\right]$ \\
\hline thomsonit-Ca & Soutěsky & tato práce & $13.105(3)$ & $13.053(2)$ & $13.243(3)$ & $2265.5(6)$ \\
thomsonit-Ca & & Stahl et al. (1990) & $13.1043(14)$ & $13.0569(18)$ & $13.2463(30)$ & 2266.46 \\
thomsonit-Ca & Tachov & Pauliš et al. (2017) & $13.1081(14)$ & $13.0558(18)$ & $13.2448(16)$ & $2266.7(5)$ \\
thomsonit-Ca & Jehla & Pauliš et al. (2015b) & $13.104(2)$ & $13.056(1)$ & $13.247(2)$ & $2266.4(6)$ \\
thomsonit-Ca & Babětín & Pauliš et al. (2018a) & $13.1049(12)$ & $13.0559(13)$ & $13.2464(12)$ & $2266.4(4)$ \\
thomsonit-Ca & Heřmanice & Pauliš et al. (2018b) & $13.104(2)$ & $13.0570(19)$ & $13.245(3)$ & $2266.2(6)$ \\
thomsonit-Ca & Hackenberg & Pauliš et al. (2014) & $13.104(2)$ & $13.056(1)$ & $13.247(2)$ & $2266.4(6)$ \\
\hline
\end{tabular}

Tabulka 6 Chemické složení thomsonitu-Ca ze Soutěsek (hm. \%)

\begin{tabular}{lrrrrrrr}
\hline & mean & 1 & 2 & 3 & 4 & 5 & 6 \\
\hline $\mathrm{SiO}_{2}$ & 37.47 & 37.28 & 37.20 & 36.94 & 37.63 & 36.78 & 38.96 \\
$\mathrm{Al}_{2} \mathrm{O}_{3}$ & 29.74 & 29.46 & 29.69 & 29.84 & 30.04 & 30.27 & 29.13 \\
$\mathrm{CaO}$ & 11.45 & 11.53 & 11.34 & 11.47 & 11.77 & 11.62 & 10.99 \\
$\mathrm{SrO}$ & 1.60 & 1.32 & 2.28 & 1.95 & 1.84 & 1.16 & 1.06 \\
$\mathrm{Na}_{2} \mathrm{O}$ & 4.39 & 4.71 & 3.84 & 4.45 & 4.21 & 4.23 & 4.92 \\
$\mathrm{H}_{2} \mathrm{O}$ & 13.04 & 13.01 & 12.96 & 12.99 & 13.14 & 12.98 & 13.70 \\
\hline total & 97.69 & 97.31 & 97.31 & 97.64 & 98.63 & 97.04 & 98.76 \\
\hline $\mathrm{Si}^{4+}$ & 5.169 & 5.156 & 5.163 & 5.117 & 5.150 & 5.098 & 5.115 \\
$\mathrm{Al}^{3+}$ & 4.836 & 4.802 & 4.857 & 4.872 & 4.845 & 4.945 & 4.507 \\
$\mathrm{Ca}^{2+}$ & 1.693 & 1.709 & 1.686 & 1.702 & 1.726 & 1.726 & 1.546 \\
$\mathrm{Sr}^{2+}$ & 0.128 & 0.145 & 0.183 & 0.156 & 0.146 & 0.093 & 0.081 \\
$\mathrm{Na}^{+}$ & 1.174 & 1.263 & 1.034 & 1.195 & 1.117 & 1.136 & 1.253 \\
\hline$\Sigma \mathrm{Ca}+\mathrm{Sr}$ & 1.302 & 1.408 & 1.217 & 1.351 & 1.263 & 1.229 & 1.334 \\
\hline $\mathrm{H}_{2} \mathrm{O}$ & 6 & 6 & 6 & 6 & 6 & 6 & 6 \\
$\mathrm{~T}_{\mathrm{Si}}$ & 0.52 & 0.52 & 0.52 & 0.51 & 0.52 & 0.51 & 0.53 \\
\hline $\mathrm{Empin}$
\end{tabular}

Empirický vzorec byl přepočten na bázi 20 atomů kyslíku. $\mathrm{H}_{2} \mathrm{O}$ bylo dopočítáno na základě teoretického obsahu $6 \mathrm{H}_{2} \mathrm{O}$. 
Tabulka 7 Rentgenová prášková data phillipsitu-K ze Soutěsek

\begin{tabular}{|c|c|c|c|c|c|c|c|c|c|c|c|c|c|c|c|c|c|}
\hline$h$ & $k$ & I & $d_{o b s}$ & $I_{o b s}$ & $d_{\text {calc }}$ & $h$ & $k$ & $I$ & $d_{o b s}$ & $I_{o b s}$ & $d_{\text {calc }}$ & $h$ & $k$ & 1 & $d_{o b s}$ & $I_{o b s}$ & $d_{\text {calc }}$ \\
\hline-1 & 1 & 1 & 7.087 & 85 & 7.103 & 0 & 1 & 3 & 2.3561 & 1 & 2.3561 & 4 & 0 & 1 & 1.7160 & 2 & 1.7157 \\
\hline 0 & 1 & 1 & 6.354 & 22 & 6.408 & -1 & 6 & 1 & 2.2896 & 1 & 2.2903 & -2 & 1 & 5 & 1.6765 & 2 & 1.6766 \\
\hline 1 & 2 & 0 & 5.339 & 32 & 5.374 & 2 & 4 & 1 & 2.2534 & 2 & 2.2515 & 1 & 5 & 3 & 1.6417 & 1 & 1.6411 \\
\hline 0 & 2 & 1 & 5.028 & 33 & 5.064 & -4 & 2 & 3 & 2.2312 & 5 & 2.2315 & 2 & 8 & 0 & 1.6378 & 2 & 1.6379 \\
\hline-2 & 0 & 1 & 4.910 & 15 & 4.962 & -4 & 2 & 1 & 2.2251 & 4 & 2.2242 & -5 & 1 & 5 & 1.6260 & 1 & 1.6257 \\
\hline-2 & 1 & 1 & 4.649 & 7 & 4.688 & -1 & 4 & 3 & 2.1860 & 2 & 2.1846 & -6 & 2 & 3 & 1.6105 & $<1$ & 1.6114 \\
\hline 1 & 0 & 1 & 4.294 & 18 & 4.295 & 3 & 0 & 1 & 2.1603 & 1 & 2.1600 & -3 & 6 & 4 & 1.6059 & 1 & 1.6063 \\
\hline 1 & 3 & 0 & 4.113 & 16 & 4.116 & 2 & 0 & 2 & 2.1475 & 4 & 2.1473 & -2 & 3 & 5 & 1.5910 & $<1$ & 1.5915 \\
\hline-2 & 0 & 2 & 4.086 & 50 & 4.091 & 2 & 1 & 2 & 2.1253 & 1 & 2.1236 & 3 & 4 & 2 & 1.5625 & 1 & 1.5622 \\
\hline 2 & 1 & 0 & 3.908 & 8 & 3.913 & 2 & 2 & 2 & 2.0556 & 1 & 2.0568 & -4 & 7 & 3 & 1.5430 & 2 & 1.5422 \\
\hline 2 & 2 & 0 & 3.532 & 1 & 3.537 & 2 & 5 & 1 & 2.0370 & 1 & 2.0362 & -1 & 6 & 4 & 1.5357 & 1 & 1.5361 \\
\hline 0 & 1 & 2 & 3.461 & 7 & 3.476 & -3 & 3 & 4 & 1.9770 & 2 & 1.9773 & -5 & 6 & 2 & 1.5166 & $<1$ & 1.5164 \\
\hline 1 & 3 & 1 & 3.188 & 100 & 3.192 & -3 & 5 & 3 & 1.9734 & 1 & 1.9746 & -5 & 4 & 5 & 1.4876 & 3 & 1.4881 \\
\hline-2 & 3 & 2 & 3.112 & 39 & 3.106 & -4 & 4 & 1 & 1.9581 & 2 & 1.9585 & -4 & 5 & 5 & 1.4787 & 1 & 1.4780 \\
\hline-2 & 0 & 3 & 2.911 & 18 & 2.913 & -1 & 2 & 4 & 1.9318 & $<1$ & 1.9330 & 1 & 4 & 4 & 1.4387 & $<1$ & 1.4384 \\
\hline 1 & 0 & 2 & 2.751 & 18 & 2.750 & -4 & 3 & 4 & 1.8783 & 1 & 1.8799 & -6 & 3 & 1 & 1.4295 & $<1$ & 1.4295 \\
\hline-3 & 0 & 3 & 2.738 & 42 & 2.727 & -2 & 7 & 2 & 1.8304 & 2 & 1.8291 & 5 & 0 & 1 & 1.4211 & 1 & 1.4209 \\
\hline-1 & 5 & 1 & 2.703 & 29 & 2.702 & -5 & 1 & 1 & 1.8150 & 1 & 1.8142 & 3 & 6 & 2 & 1.4040 & 1 & 1.4039 \\
\hline-2 & 4 & 2 & 2.690 & 46 & 2.693 & 1 & 6 & 2 & 1.8002 & 1 & 1.8019 & -2 & 9 & 3 & 1.3958 & $<1$ & 1.3959 \\
\hline-3 & 3 & 1 & 2.667 & 19 & 2.668 & 0 & 8 & 0 & 1.7893 & 5 & 1.7893 & 4 & 6 & 1 & 1.3930 & $<1$ & 1.3929 \\
\hline 1 & 2 & 2 & 2.5672 & 3 & 2.5667 & -4 & 4 & 4 & 1.7758 & 3 & 1.7757 & -5 & 3 & 6 & 1.3696 & 3 & 1.3692 \\
\hline 3 & 2 & 0 & 2.5356 & 1 & 2.5361 & 4 & 4 & 0 & 1.7692 & 4 & 1.7684 & -5 & 7 & 4 & 1.3668 & 2 & 1.3664 \\
\hline-4 & 1 & 2 & 2.4499 & 3 & 2.4444 & -3 & 5 & 4 & 1.7307 & $<1$ & 1.7306 & 0 & 7 & 4 & 1.3482 & 1 & 1.3475 \\
\hline 1 & 3 & 2 & 2.3833 & 9 & 2.3823 & & & & & & & & & & & & \\
\hline
\end{tabular}

Tabulka 8 Parametry základní cely phillipsitu (pro monoklinickou prostorovou grupu $P 2_{1} / \mathrm{m}$ )

\begin{tabular}{|c|c|c|c|c|c|c|c|}
\hline & & & $a[\AA]$ & $b[\AA]$ & $c[\AA]$ & $\beta\left[^{\circ}\right]$ & $V\left[\AA^{3}\right]$ \\
\hline phillipsit-K & Soutěsky & tato práce & $9.924(3)$ & $14.314(4)$ & $8.740(2)$ & $124.93(2)$ & $1017.9(5)$ \\
\hline phillipsit-Ca & Poustevna & Pauliš et al. (2019) & $9.9206(19)$ & $14.315(3)$ & $8.7387(19)$ & $124.92(6$ & $1017.5(4)$ \\
\hline phillipsit-Ca & Zaječí vrch & Pauliš et al. (2019) & $9.9226(19)$ & $14.314(3)$ & $8.7396(17)$ & $124.92(5)$ & $1017.8(4)$ \\
\hline phillipsit-Ca & Heřmanice & Pauliš et al. (2018b) & $9.922(19)$ & $14.314(4)$ & $8.742(18)$ & $124.91(3)$ & $1018.0(4)$ \\
\hline phillipsit-K & Svor & Pauliš et al. (2016b) & $9.924(2)$ & $14.315(3)$ & $8.742(2)$ & $124.93(7)$ & $1018.2(4)$ \\
\hline phillipsit-K & Nový Oldřichov & Pauliš et al. (2016a) & $9.925(1)$ & $14.312(3)$ & $8.740(2)$ & $124.92(3)$ & 1018.0(3) \\
\hline phillipsit-Ca & Nový Oldřichov & Pauliš et al. (2016a) & $9.922(1)$ & $14.313(3)$ & $8.743(2)$ & $124.91(2)$ & 1018.1(3) \\
\hline phillipsit & & Gatta et al. (2009) & $9.9238(6)$ & $14.3145(5)$ & $8.7416(5)$ & $124.920(9)$ & 1018.2 \\
\hline
\end{tabular}

Tabulka 9 Chemické složení phillipsitu-K ze Soutěsek (hm. \%)

\begin{tabular}{lrrrrrrr}
\hline & mean & 1 & 2 & 3 & 4 & 5 & 6 \\
\hline $\mathrm{SiO}_{2}$ & 47.94 & 47.93 & 47.00 & 47.47 & 47.67 & 48.72 & 48.85 \\
$\mathrm{Al}_{2} \mathrm{O}_{3}$ & 20.93 & 21.25 & 21.53 & 21.25 & 20.77 & 20.82 & 19.96 \\
$\mathrm{CaO}$ & 7.44 & 7.51 & 7.65 & 7.52 & 7.34 & 7.48 & 7.16 \\
$\mathrm{BaO}$ & 0.16 & 0.13 & 0.24 & 0.20 & 0.13 & 0.12 & 0.15 \\
$\mathrm{~K}{ }_{2} \mathrm{O}$ & 7.97 & 8.53 & 8.19 & 7.35 & 7.48 & 8.08 & 8.20 \\
$\mathrm{Na}_{2} \mathrm{O}$ & 0.91 & 0.93 & 1.07 & 1.00 & 1.09 & 0.91 & 0.48 \\
$\mathrm{H}_{2} \mathrm{O}$ & 16.51 & 16.62 & 16.48 & 16.45 & 16.39 & 16.68 & 16.46 \\
\hline total & 101.86 & 102.90 & 102.16 & 101.24 & 100.87 & 102.81 & 101.26 \\
\hline $\mathrm{Si}^{4+}$ & 10.445 & 10.373 & 10.258 & 10.383 & 10.461 & 10.509 & 10.676 \\
$\mathrm{Al}^{3+}$ & 5.375 & 5.420 & 5.539 & 5.478 & 5.372 & 5.293 & 5.143 \\
$\mathrm{Ca}^{2+}$ & 1.737 & 1.741 & 1.789 & 1.763 & 1.726 & 1.729 & 1.677 \\
$\mathrm{Ba}^{2+}$ & 0.013 & 0.010 & 0.021 & 0.017 & 0.011 & 0.010 & 0.013 \\
$\mathrm{~K}^{+}$ & 2.215 & 2.356 & 2.279 & 2.050 & 2.094 & 2.224 & 2.285 \\
$\mathrm{Na}^{+}$ & 0.385 & 0.390 & 0.454 & 0.423 & 0.464 & 0.381 & 0.202 \\
\hline$\Sigma \mathrm{Ca}+\mathrm{Ba}+\mathrm{K}+\mathrm{Na}$ & 4.350 & 4.497 & 4.543 & 4.253 & 4.295 & 4.344 & 4.177 \\
\hline $\mathrm{H}_{2} \mathrm{O}$ & 12 & 12 & 12 & 12 & 12 & 12 & 12 \\
$\mathrm{~T}_{\mathrm{Si}}$ & 0.66 & 0.65 & 0.65 & 0.65 & 0.66 & 0.66 & 0.67 \\
\hline
\end{tabular}

Empirický vzorec byl přepočten na bázi 32 atomů kyslíku. $\mathrm{H}_{2} \mathrm{O}$ byla dopočítána na základě teoretického obsahu $12 \mathrm{H}_{2} \mathrm{O}$. 
ní druh, zpřesněné mřížkové parametry dobře odpovídají publikovaným údajům pro tento zeolit (tab. 14). V BSE obraze je minerál chemicky poměrně homogenní. Chemickou analýzou byly zjištěny obsahy $\mathrm{Si}, \mathrm{Al}, \mathrm{Ca}, \mathrm{Ba}, \mathrm{Sr}$, $\mathrm{K}$ a Na; ostatní měřené prvky jsou pod mezí detekce (tab. 15). Empirický vzorec (průměr čtyř bodových analýz) na bázi 24 atomů kyslíku je možno vyjádřit jako $\left(\mathrm{Ca}_{1.44} \mathrm{~K}_{1.26}\right.$ $\left.\mathrm{Sr}_{0.28} \mathrm{Na}_{0.15} \mathrm{Ba}_{0.01}\right)_{\Sigma 3.14}\left(\mathrm{Al}_{3.65} \mathrm{Si}_{8.04} \mathrm{O}_{24}\right) \cdot 12 \mathrm{H}_{2} \mathrm{O}$. Většinou jde o chabazit-Ca, v jedné bodové analýze však obsah $\mathrm{K}$ apfu převažuje nad Ca apfu. Hodnota $\mathrm{T}_{\mathrm{Si}}=\mathrm{Si} /(\mathrm{Si}+\mathrm{Al})=0.69$ je ve střední části rozmezí uváděného pro chabazit-Ca (Coombs et al. 1997).

Analcim byl zjištěn jen v několika drobných dutinách na vzorku s chabazitem-Ca. Vytváří souvislou výstelku tvořenou čirými, skelně lesklými trapezoedry maximálně $0.4 \mathrm{~mm}$ velkými.

Rentgenová prášková data analcimu ze Soutěsek (tab. 16) jsou blízká datům pro tento minerální druh, zpřesněné mřížkové parametry odpovídají publikovaným údajům pro tento zeolit (tab. 17). V BSE obraze je studovaný minerál homogenní. Při studiu chemického složení byly zjištěny obsahy $\mathrm{Si}, \mathrm{Al}$ a Na; ostatní měřené prvky byly pod mezí detekce (tab. 18). Empirický vzorec analcimu (průměr tří bodových analýz) na bázi 6 atomů kyslíku je možno vyjádřit jako $\mathrm{Na}_{0.98}\left(\mathrm{Al}_{0.94} \mathrm{Si}_{2.04} \mathrm{O}_{6}\right) \cdot \mathrm{H}_{2} \mathrm{O}$. Hodnota $\mathrm{T}_{\mathrm{Si}}=\mathrm{Si} /(\mathrm{Si}+\mathrm{Al})=0.68$ se nachází $\mathrm{v}$ horním limitu rozmezí uváděného pro analcim (Coombs et al. 1997).

Tabulka 10 Rentgenová prášková data gismondinu ze Soutěsek

\begin{tabular}{|c|c|c|c|c|c|c|c|c|c|c|c|c|c|c|c|c|c|}
\hline$h$ & $k$ & I & $d_{o b s}$ & $I_{o b s}$ & $d_{c a l c}$ & $h$ & $k$ & I & $d_{o b s}$ & $I_{o b s}$ & $d_{\text {calc }}$ & $h$ & $k$ & I & $d_{o b s}$ & $I_{o b s}$ & $d_{\text {calc }}$ \\
\hline 1 & 1 & 0 & 7.273 & 61 & 7.288 & -1 & 4 & 1 & 2.4912 & 18 & 2.4918 & 5 & 3 & 1 & 1.7060 & 1 & 1.7052 \\
\hline-1 & 1 & 1 & 5.929 & 5 & 5.943 & 2 & 3 & 2 & 2.4630 & 10 & 2.4647 & -4 & 2 & 4 & 1.6989 & 2 & 1.6982 \\
\hline 1 & 1 & 1 & 5.755 & 14 & 5.765 & 3 & 3 & 0 & 2.4269 & 3 & 2.4293 & 2 & 4 & 4 & 1.6787 & 1 & 1.6793 \\
\hline 0 & 2 & 0 & 5.307 & 3 & 5.315 & 0 & 3 & 3 & 2.4021 & 8 & 2.4042 & 2 & 6 & 0 & 1.6699 & 10 & 1.6701 \\
\hline 2 & 0 & 0 & 4.994 & 8 & 5.006 & -4 & 1 & 1 & 2.3890 & 1 & 2.3885 & 0 & 6 & 2 & 1.6663 & 1 & 1.6664 \\
\hline 0 & 0 & 2 & 4.903 & 39 & 4.909 & -1 & 3 & 3 & 2.3583 & $<1$ & 2.3550 & 6 & 1 & 0 & 1.6480 & 5 & 1.6484 \\
\hline 0 & 2 & 1 & 4.666 & 16 & 4.674 & 2 & 4 & 0 & 2.3474 & 3 & 2.3472 & 1 & 6 & 2 & 1.6397 & 5 & 1.6399 \\
\hline 2 & 1 & 0 & 4.530 & 1 & 4.529 & -4 & 0 & 2 & 2.2709 & $<1$ & 2.2704 & 5 & 3 & 2 & 1.6251 & 1 & 1.6233 \\
\hline-1 & 0 & 2 & 4.476 & 1 & 4.486 & -2 & 0 & 4 & 2.2409 & 2 & 2.2431 & 1 & 0 & 6 & 1.6033 & 1 & 1.6038 \\
\hline 0 & 1 & 2 & 4.450 & 9 & 4.457 & -4 & 2 & 1 & 2.2266 & 1 & 2.2259 & 5 & 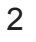 & 3 & 1.5973 & $<1$ & 1.5981 \\
\hline 1 & 0 & 2 & 4.328 & 1 & 4.333 & 4 & 2 & 1 & 2.1887 & 4 & 2.1876 & -5 & 0 & 4 & 1.5863 & 1 & 1.5860 \\
\hline-1 & 2 & 1 & 4.263 & 82 & 4.269 & 3 & 3 & 2 & 2.1489 & 2 & 2.1502 & 0 & 4 & 5 & 1.5794 & 2 & 1.5793 \\
\hline 1 & 2 & 1 & 4.196 & 32 & 4.202 & -2 & 4 & 2 & 2.1325 & 4 & 2.1347 & . & $T$ & 3 & 1.5721 & 1 & 1.5708 \\
\hline-1 & 1 & 2 & 4.129 & 1 & 4.133 & 3 & 2 & 3 & 2.1004 & 4 & 2.1009 & -3 & 6 & 1 & 1.5503 & 4 & 1.5503 \\
\hline 2 & 1 & 1 & 4.046 & 19 & 4.052 & -4 & 2 & 2 & 2.0915 & 10 & 2.0879 & 4 & 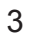 & 4 & 1.5441 & 2 & 1.5439 \\
\hline 2 & 2 & 0 & 3.638 & 10 & 3.644 & 0 & 4 & 3 & 2.0625 & 1 & 2.0630 & 2 & 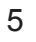 & 4 & 1.5169 & 2 & 1.5175 \\
\hline-2 & 0 & 2 & 3.577 & 1 & 3.584 & 4 & 3 & 0 & 2.0426 & 7 & 2.0443 & 3 & 3 & 5 & 1.5045 & $<1$ & 1.5039 \\
\hline-2 & 2 & 1 & 3.450 & 1 & 3.452 & 1 & 5 & 1 & 2.0301 & 4 & 2.0307 & -6 & 3 & 1 & 1.5007 & $<1$ & 1.5010 \\
\hline 2 & 2 & 1 & 3.375 & 7 & 3.381 & 1 & 4 & 3 & 2.0093 & $y$ & 2.0096 & -6 & r & 3 & 1.4985 & 1 & 1.4985 \\
\hline 1 & 2 & 2 & 3.354 & 8 & 3.359 & -3 & 3 & 3 & 1.9809 & $<1$ & 1.9812 & -3 & 0 & 6 & 1.4955 & 2 & 1.4954 \\
\hline 3 & 0 & 0 & 3.336 & 22 & 3.337 & 1 & 3 & 4 & 1.9638 & 4 & 1.9643 & -1 & 0 & 6 & 1.4780 & 1 & 1.4781 \\
\hline 2 & 1 & 2 & 3.270 & 3 & 3.265 & 0 & 1 & 5 & 1.9303 & 3 & 1.9310 & -6 & 3 & 2 & 1.4597 & 1 & 1.4592 \\
\hline-1 & 3 & 1 & 3.176 & 100 & 3.176 & -4 & 3 & 2 & 1.9110 & 10 & 1.9116 & -6 & 2 & 3 & 1.4561 & $<1$ & 1.4557 \\
\hline 0 & 1 & 3 & 3.125 & 45 & 3.128 & -2 & 3 & 4 & 1.8949 & $<1$ & 1.8953 & -1 & 7 & 2 & 1.4392 & 1 & 1.4384 \\
\hline-1 & 1 & 3 & 3.032 & 70 & 3.022 & 5 & 2 & 0 & 1.8742 & 7 & 1.8738 & 2 & 7 & 1 & 1.4357 & 1 & 1.4349 \\
\hline 3 & 1 & 1 & 2.988 & 8 & 2.992 & 2 & 3 & 4 & 1.8482 & 2 & 1.8485 & 3 & 1 & 6 & 1.4320 & 1 & 1.4313 \\
\hline 1 & 1 & 3 & 2.945 & 2 & 2.951 & 3 & 2 & 4 & 1.8209 & 3 & 1.8201 & -5 & 1 & 5 & 1.4210 & 6 & 1.4209 \\
\hline 0 & 3 & 2 & 2.870 & 3 & 2.873 & -4 & 4 & 1 & 1.8023 & 3 & 1.8018 & 3 & 6 & 3 & 1.4012 & $<1$ & 1.4006 \\
\hline-3 & 2 & 1 & 2.739 & 52 & 2.743 & -4 & 0 & 4 & 1.7915 & 3 & 1.7922 & -6 & 1 & 4 & 1.3969 & 7 & 1.3967 \\
\hline-3 & 1 & 2 & 2.719 & 4 & 2.724 & 0 & 5 & 3 & 1.7830 & 6 & 1.7828 & -1 & 4 & 6 & 1.3872 & 1 & 1.3872 \\
\hline 3 & 0 & 2 & 2.708 & 35 & 2.705 & 0 & 6 & 0 & 1.7722 & 1 & 1.7716 & 1 & 4 & 6 & 1.3740 & 2 & 1.3731 \\
\hline 0 & 4 & 0 & 2.657 & 44 & 2.657 & -3 & 3 & 4 & 1.7547 & 6 & 1.7549 & 3 & 7 & 1 & 1.3652 & $<1$ & 1.3653 \\
\hline 3 & 1 & 2 & 2.618 & 8 & 2.622 & -2 & 2 & 5 & 1.7529 & 7 & 1.7522 & -2 & 4 & 6 & 1.3561 & 1 & 1.3555 \\
\hline 2 & 1 & 3 & 2.602 & 3 & 2.604 & 3 & 4 & 3 & 1.7333 & $<1$ & 1.7335 & 6 & 3 & 3 & 1.3504 & 1 & 1.3506 \\
\hline 0 & 4 & 1 & 2.5635 & 4 & 2.5652 & 4 & 0 & 4 & 1.7152 & 2 & 1.7153 & & & & & & \\
\hline
\end{tabular}

Tabulka 11 Parametry základní cely gismondinu (pro monoklinickou prostorovou grupu P2//c)

\begin{tabular}{rcccc}
\hline & tato práce & Rinaldi, Vezzalini (1985) & Pauliš et al. (2014) & Pauliš et al. (2015b) \\
\hline$a[\AA]$ & $10.0212(13)$ & $10.0197(7)$ & $10.021(2)$ & $10.019(5)$ \\
$b[\AA]$ & $10.6298(15)$ & $10.6347(7)$ & $10.630(3)$ & $10.639(4)$ \\
$c[\AA]$ & $9.8279(13)$ & $9.8323(5)$ & $9.828(3)$ & $9.832(4)$ \\
$\beta\left[\left[^{\circ}\right]\right.$ & $92.51(3)$ & $92.511(7)$ & 92.51 & $92.54(4)$ \\
$V\left[\AA^{3}\right]$ & $1045.9(2)$ & 1046.69 & $1045.8(5)$ & $1045(8)$ \\
\hline
\end{tabular}


Tabulka 12 Chemické složení gismondinu ze Soutěsek (hm. \%)

\begin{tabular}{lrrrrrr}
\hline & mean & 1 & 2 & 3 & 4 & 5 \\
\hline $\mathrm{SiO}_{2}$ & 37.79 & 37.88 & 37.76 & 37.13 & 37.98 & 38.22 \\
$\mathrm{Al}_{2} \mathrm{O}_{3}$ & 30.24 & 30.39 & 30.93 & 29.81 & 29.89 & 30.16 \\
$\mathrm{CaO}$ & 16.41 & 16.47 & 16.28 & 16.32 & 16.59 & 16.41 \\
$\mathrm{Na}_{2} \mathrm{O}$ & 0.14 & 0 & 0.33 & 0.29 & 0.10 & 0 \\
$\mathrm{H}_{2} \mathrm{O}$ & 24.75 & 24.81 & 24.96 & 24.41 & 24.74 & 24.85 \\
\hline total & 109.33 & 109.55 & 110.26 & 107.96 & 109.30 & 109.64 \\
\hline $\mathrm{Si}^{4+}$ & 2.060 & 2.060 & 2.041 & 2.052 & 2.039 & 2.076 \\
$\mathrm{Al}^{3+}$ & 1.943 & 1.948 & 1.971 & 1.942 & 1.935 & 1.930 \\
$\mathrm{Ca}^{2+}$ & 0.958 & 0.959 & 0.943 & 0.966 & 0.976 & 0.955 \\
$\mathrm{Na}^{+}$ & 0.016 & 0 & 0.034 & 0.031 & 0.011 & 0 \\
\hline$\Sigma \mathrm{Ca}+\mathrm{Na}$ & 0.974 & 0.959 & 0.977 & 0.997 & 0.987 & 0.955 \\
\hline $\mathrm{H}_{2} \mathrm{O}$ & 4.5 & 4.5 & 4.5 & 4.5 & 4.5 & 4.5 \\
$\mathrm{~T}_{\mathrm{Si}}$ & 0.51 & 0.51 & 0.51 & 0.51 & 0.51 & 0.52 \\
\hline $\mathrm{Empi}$ & & & &
\end{tabular}

Empirický vzorec byl přepočten na bázi 8 atomů kyslíku. $\mathrm{H}_{2} \mathrm{O}$ byla dopočíána na základě teoretického obsahu $4.5 \mathrm{H}_{2} \mathrm{O}$.
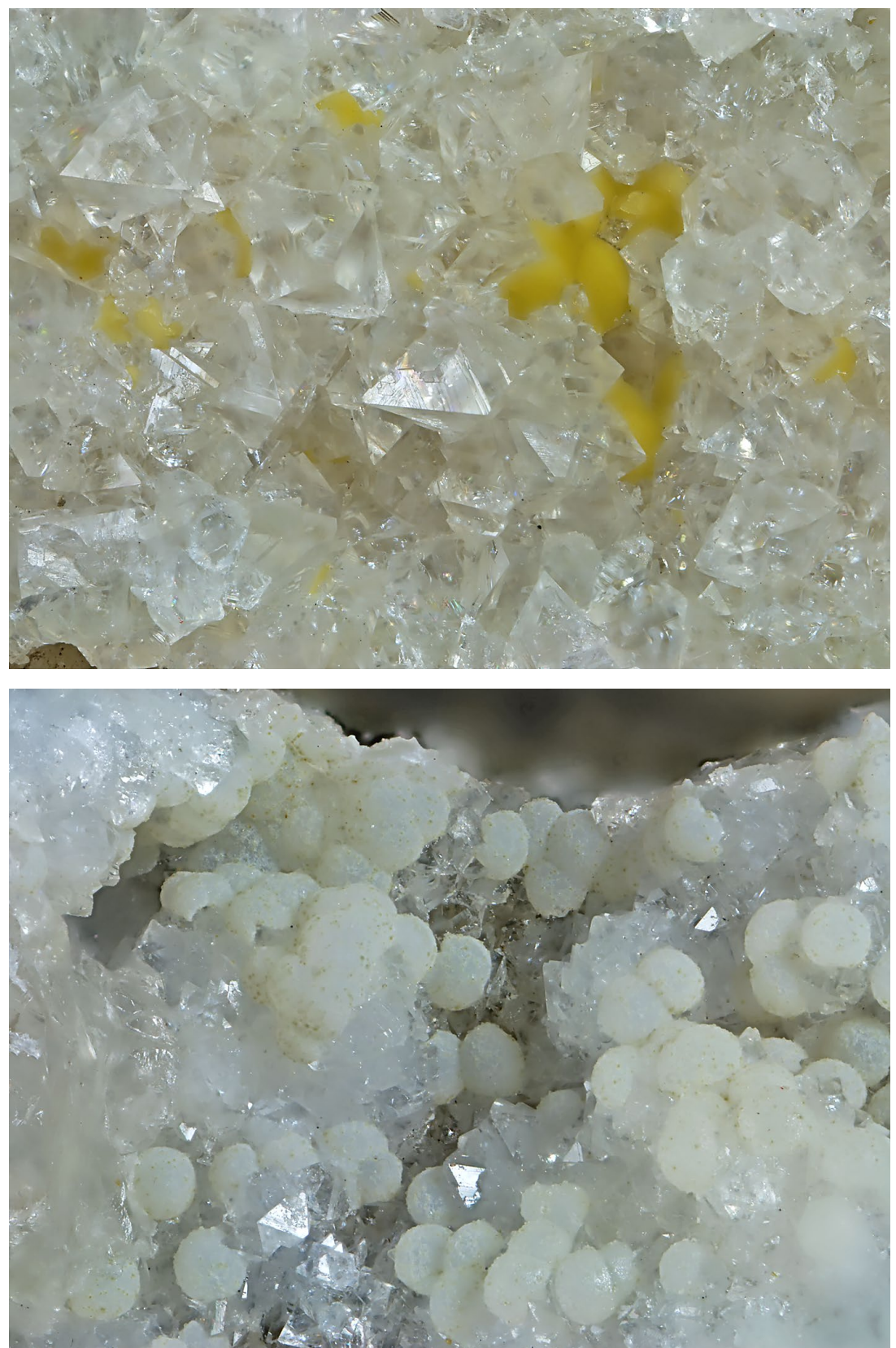

Natrolit je na lokalitě, na rozdíl od nedalekého lomu, minerálem vzácným. Nalezen byl pouze v několika málo vzorcích. Vytváří bezbarvé až bělavé štětičkové agregáty $z$ jednotlivě vyvinutých, různě dlouhých jehliček až $2 \mathrm{~mm}$ dlouhých, nebo kulovité agregáty průměru do $4 \mathrm{~mm}$. Pravděpodobně srůstá $s$ thomsonitem-Ca. Analyzována byla pouze nestechiometrická čistě sodná fáze pravděpodobného natrolitu srůstajícího s thomsonitem-Ca.

Kalcit se v dutinách vyskytuje patrně ve třech generacích. $V$ podobě jemně zrnité vrstvy vytváŕí na některých místech základní výstelku dutin, na kterou nasedají phillipsit-K a gismondin. $V$ další generaci tvoři kalcit opět souvislou vrstvu, vzácně i pěkně vyvinuté krystaly, které porůstají thomsonit-Ca. Kalcit patrně též tvořil zóny $v$ agregátech böhmitu, které po vyloužení poskytly prázdné prostory, místy následně vyplněné thomsonitem-Ca. Nejmladší generace kalcitu tvoří až $1 \mathrm{~cm}$ velké bezbarvé, vínové až medové, většinou klencové krystaly $v$ dutinách. Někdy dutiny zcela vyplňuje.

Několik set metrů sz. od lokality böhmitu se nacházejí dvě naleziště pěkně krystalovaného „augitu“. Několik metrů mocná poloha světle hnědých pyroklastik obsahuje matné černé krystaly tlustě tabulkového tvaru o velikosti až $1 \mathrm{~cm}$. Zajímavější jsou krystaly z autometamorfně rozloženého vulkanitu, jehož výchoz o něco níže ve svahu objevil již nežijící teplický sběratel Josef Rychtecký v roce 1985. Kŕižové prorostlice tence tabulkovitých, lesklých, dokonale omezených krystalů jsou až $15 \mathrm{~mm}$ dlouhé a cca $2 \mathrm{~mm}$ tlusté. Ze silně rozloženého vulkanitu je Ize vypreparovat bez poškození (obr. 18). Augit někdy vytváří i mnohočetné prorostlice kolem $1 \mathrm{~cm}$ velké, složené z velice tenkých

Obr. 16 Vzácná asociace gismondinu s böhmitem, lokalita Soutěsky - nad lomem. Šiŕka záběru 5.8 $\mathrm{mm}$, foto $B$. Bureš.

Obr. 17 Gismondin s böhmitem, lokalita Soutěsky - nad lomem. Šírka záběru $3.9 \mathrm{~mm}$, foto $B$. Bureš. 
Tabulka 13 Rentgenová prášková data chabazitu-Ca ze Soutěsek

\begin{tabular}{cccccccccccccccccc}
\hline$h$ & $k$ & $l$ & $d_{\text {obs }}$ & $l_{\text {obs }}$ & $d_{c a l c}$ & $h$ & $k$ & $l$ & $d_{\text {obs }}$ & $l_{\text {obs }}$ & $d_{c a l c}$ & $h$ & $k$ & $l$ & $d_{\text {obs }}$ & $l_{\text {obs }}$ & $d_{\text {calc }}$ \\
\hline 1 & 0 & 1 & 9.396 & 10 & 9.359 & 4 & 0 & 4 & 2.3461 & 1 & 2.3398 & 4 & 4 & 3 & 1.6320 & 1 & 1.6333 \\
0 & 1 & 2 & 6.301 & 4 & 6.359 & 3 & 3 & 0 & 2.3029 & 1 & 2.3039 & 1 & 1 & 9 & 1.6182 & $<1$ & 1.6212 \\
0 & 2 & 1 & 5.513 & 10 & 5.560 & 3 & 1 & 5 & 2.2289 & 1 & 2.2267 & 0 & 4 & 8 & 1.5880 & 1 & 1.5896 \\
0 & 0 & 3 & 4.989 & 8 & 5.003 & 3 & 2 & 4 & 2.2199 & 1 & 2.2162 & 7 & 1 & 0 & 1.5861 & $<1$ & 1.5857 \\
2 & 1 & 1 & 4.303 & 100 & 4.332 & 3 & 0 & 6 & 2.1195 & 1 & 2.1195 & 2 & 3 & 8 & 1.5529 & 7 & 1.5492 \\
1 & 1 & 3 & 4.075 & 2 & 4.053 & 1 & 0 & 7 & 2.1136 & 1 & 2.1106 & 6 & 2 & 4 & 1.5182 & 1 & 1.5182 \\
3 & 0 & 0 & 4.025 & 1 & 3.990 & 6 & 0 & 0 & 1.9907 & 1 & 1.9952 & 7 & 1 & 3 & 1.5120 & $<1$ & 1.5116 \\
1 & 0 & 4 & 3.562 & 24 & 3.581 & 2 & 1 & 7 & 1.9403 & 2 & 1.9376 & 5 & 3 & 5 & 1.4869 & 1 & 1.4860 \\
2 & 2 & 0 & 3.451 & 1 & 3.456 & 3 & 4 & 2 & 1.9057 & 4 & 1.9037 & 4 & 3 & 7 & 1.4486 & 1 & 1.4499 \\
1 & 3 & 1 & 3.245 & 2 & 3.242 & 5 & 1 & 4 & 1.8643 & 7 & 1.8656 & 4 & 2 & 8 & 1.4461 & $<1$ & 1.4442 \\
0 & 2 & 4 & 3.182 & 1 & 3.179 & 6 & 0 & 3 & 1.8522 & $<1$ & 1.8533 & 4 & 4 & 6 & 1.4242 & $<1$ & 1.4217 \\
3 & 0 & 3 & 3.111 & 1 & 3.120 & 1 & 3 & 7 & 1.7995 & 17 & 1.8013 & 5 & 4 & 4 & 1.4184 & $<1$ & 1.4190 \\
0 & 1 & 5 & 2.913 & 66 & 2.912 & 4 & 4 & 0 & 1.7292 & 1 & 1.7279 & 1 & 5 & 8 & 1.4144 & 2 & 1.4137 \\
2 & 1 & 4 & 2.875 & 19 & 2.888 & 3 & 2 & 7 & 1.6885 & 3 & 1.6901 & 4 & 1 & 9 & 1.4040 & 1 & 1.4057 \\
2 & 2 & 3 & 2.827 & 3 & 2.843 & 5 & 3 & 2 & 1.6654 & 2 & 1.6675 & 0 & 8 & 4 & 1.3892 & 1 & 1.3900 \\
2 & 0 & 5 & 2.674 & 9 & 2.683 & 1 & 6 & 4 & 1.6418 & 3 & 1.6416 & 3 & 4 & 8 & 1.3610 & $<1$ & 1.3580 \\
1 & 3 & 4 & 2.4920 & 14 & 2.4866 & & & & & & & & & & \\
\hline
\end{tabular}

Tabulka 14 Parametry základní cely chabazitu-Ca (pro trigonální prostorovou grupu R-3m)

\begin{tabular}{llll}
\hline & $a[\AA]$ & $c[\AA]$ & $V\left[\AA^{3}\right]$ \\
\hline chabazit (tato práce) & $13.824(6)$ & $15.0094(4)$ & $2483.9(8)$ \\
chabazit-Ca Poustevna (Pauliš et al. 2019) & $13.8088(4)$ & $15.0395(3)$ & $2482.5(7)$ \\
chabazit Zaječí vrch (Pauliš et al. 2019) & $13.819(6)$ & $15.0186(3)$ & $2483.7(8)$ \\
chabazit-Ca Heřmanice (Pauliš et al. 2018b) & $13.814(5)$ & $15.0449(3)$ & $2486.3(9)$ \\
chabazit-Ca (Yakubovich et al. 2005) & $13.831(3)$ & $15.023(5)$ & 2488.83 \\
chabazit-Ca Tachov (Pauliš et al. 2017) & $13.833(8)$ & $15.0213(3)$ & $2490(1)$ \\
chabazit-Ca Hackenberg (Pauliš et al. 2014) & $13.837(6)$ & $15.0073(4)$ & $2488(1)$ \\
chabazit-Ca Jehla (Pauliš et al. 2015b) & $13.820(6)$ & $15.0226(4)$ & $2484.9(1)$ \\
\hline
\end{tabular}

Tabulka 15 Chemické složení chabazitu-Ca ze Soutěsek (hm. \%)

\begin{tabular}{lrrrrr}
\hline & mean & 1 & 2 & 3 & 4 \\
\hline $\mathrm{SiO}_{2}$ & 45.26 & 41.39 & 43.50 & 47.33 & 48.83 \\
$\mathrm{Al}_{2} \mathrm{O}_{3}$ & 17.44 & 17.77 & 18.56 & 16.67 & 16.77 \\
$\mathrm{CaO}$ & 7.58 & 7.41 & 7.48 & 7.62 & 7.81 \\
$\mathrm{SrO}$ & 2.73 & 3.53 & 3.63 & 1.26 & 2.49 \\
$\mathrm{BaO}$ & 0.15 & 0.24 & 0.13 & 0.09 & 0.13 \\
$\mathrm{~K}_{2} \mathrm{O}$ & 5.54 & 6.69 & 5.96 & 5.39 & 4.12 \\
$\mathrm{Na}_{2} \mathrm{O}$ & 0.43 & 0.44 & 0.85 & 0.23 & 0.20 \\
$\mathrm{H}_{2} \mathrm{O}$ & 20.25 & 19.33 & 20.63 & 20.50 & 20.99 \\
\hline total & 96.80 & 101.04 & 99.09 & 101.34 \\
\hline $\mathrm{Si}^{4+}$ & 99.38 & 7.703 & 7.584 & 8.308 & 8.371 \\
$\mathrm{Al}^{3+}$ & 8.042 & 3.898 & 3.814 & 3.449 & 3.389 \\
$\mathrm{Ca}^{2+}$ & 3.651 & 1.477 & 1.398 & 1.433 & 1.435 \\
$\mathrm{Sr}^{2+}$ & 1.444 & 0.381 & 0.367 & 0.129 & 0.247 \\
$\mathrm{Ba}^{2+}$ & 0.281 & 0.018 & 0.011 & 0.006 & 0.010 \\
$\mathrm{~K}^{+}$ & 0.011 & 1.588 & 1.327 & 1.205 & 0.898 \\
$\mathrm{Na}^{+}$ & 1.256 & 0.159 & 0.287 & 0.078 & 0.066 \\
\hline$\Sigma \mathrm{Ca}+\mathrm{Sr}+\mathrm{Ba+K+Na}$ & 0.147 & 3.623 & 3.390 & 12 & 2.851 \\
\hline $\mathrm{H}_{2} \mathrm{O}$ & 3.139 & 12 & 0.67 & 12 & 12 \\
$\mathrm{~T}_{\mathrm{Si}}$ & 12 & 0.69 & & 0.71 & 0.71 \\
\hline $\mathrm{H}_{2} \mathrm{O}$. & & & & 12 \\
\hline
\end{tabular}


Tabulka 16 Rentgenová prášková data analcimu ze Soutěsek

\begin{tabular}{cccccccccccc}
\hline$h$ & $k$ & $l$ & $d_{o b s}$ & $l_{o b s}$ & $d_{c a l c}$ & $h$ & $k$ & $l$ & $d_{o b s}$ & $l_{o b s}$ & $d_{c a l c}$ \\
\hline 1 & 1 & 2 & 5.575 & 86 & 5.593 & 2 & 5 & 5 & 1.8645 & 6 & 1.8643 \\
2 & 0 & 2 & 4.829 & 18 & 4.843 & 6 & 2 & 4 & 1.8303 & 1 & 1.8307 \\
1 & 2 & 3 & 3.654 & 11 & 3.661 & 2 & 3 & 7 & 1.7393 & 10 & 1.7398 \\
0 & 0 & 4 & 3.419 & 100 & 3.423 & 0 & 0 & 8 & 1.7128 & 2 & 1.7124 \\
0 & 2 & 4 & 3.067 & 1 & 3.063 & 1 & 4 & 7 & 1.6853 & 2 & 1.6863 \\
3 & 2 & 3 & 2.917 & 75 & 2.921 & 0 & 2 & 8 & 1.6609 & 1 & 1.6613 \\
2 & 2 & 4 & 2.794 & 5 & 2.796 & 6 & 0 & 6 & 1.6149 & 1 & 1.6145 \\
1 & 3 & 4 & 2.684 & 29 & 2.687 & 3 & 4 & 7 & 1.5927 & 3 & 1.5925 \\
2 & 1 & 5 & 2.5014 & 12 & 2.5012 & 4 & 2 & 8 & 1.4955 & 1 & 1.4947 \\
4 & 0 & 4 & 2.4199 & 5 & 2.4217 & 6 & 5 & 5 & 1.4779 & 2 & 1.4772 \\
2 & 3 & 5 & 2.2206 & 6 & 2.2223 & 6 & 4 & 6 & 1.4612 & 1 & 1.4604 \\
0 & 2 & 6 & 2.1627 & 1 & 2.1661 & 5 & 4 & 7 & 1.4435 & 1 & 1.4440 \\
1 & 4 & 5 & 2.1130 & 2 & 2.1139 & 3 & 6 & 7 & 1.4133 & 18 & 1.4130 \\
3 & 1 & 6 & 2.0192 & 3 & 2.0199 & 5 & 3 & 8 & 1.3847 & 1 & 1.3839 \\
4 & 4 & 4 & 1.9776 & $<1$ & 1.9773 & 6 & 0 & 8 & 1.3704 & 1 & 1.3699 \\
3 & 4 & 5 & 1.9367 & 1 & 1.9374 & 2 & 7 & 7 & 1.3570 & 4 & 1.3564 \\
6 & 0 & 4 & 1.8986 & 22 & 1.8998 & & & & & & \\
\hline
\end{tabular}

Tabulka 17 Parametry základní cely analcimu (pro kubickou prostorovou grupu la-3d)

tato práce Gatta et al. (2006) Pauliš et al. (2014) Pauliš et al. (2017)

\begin{tabular}{ccccc}
\hline$a[\AA]$ & $13.699(4)$ & $13.6999(3)$ & $13.703(5)$ & $13.709(6)$ \\
$V\left[\AA^{3}\right]$ & $2571.1(8)$ & 2571.3 & $2573(1)$ & $2576(1)$ \\
\hline
\end{tabular}

Tabulka 18 Chemické složení analcimu ze Soutěsek (hm. \%)

\begin{tabular}{lrrrr}
\hline & mean & 1 & 2 & 3 \\
\hline $\mathrm{SiO}_{2}$ & 55.58 & 55.96 & 54.96 & 56.41 \\
$\mathrm{Al}_{2} \mathrm{O}_{3}$ & 21.83 & 21.72 & 22.08 & 21.69 \\
$\mathrm{Na}_{2} \mathrm{O}$ & 13.80 & 13.64 & 13.92 & 13.85 \\
$\mathrm{H}_{2} \mathrm{O}$ & 8.16 & 8.18 & 7.69 & 8.23 \\
\hline total & 99.37 & 99.50 & 98.06 & 100.18 \\
\hline $\mathrm{Si}^{4+}$ & 2.041 & 2.050 & 1.974 & 2.056 \\
$\mathrm{Al}^{3+}$ & 0.945 & 0.938 & 1.015 & 0.932 \\
$\mathrm{Na}^{+}$ & 0.983 & 0.985 & 1.052 & 0.979 \\
\hline $\mathrm{H}_{2} \mathrm{O}$ & 1 & 1 & 1 & 1 \\
$\mathrm{~T}_{\mathrm{Si}}$ & 0.68 & 0.69 & 0.66 & 0.69
\end{tabular}

Empirický vzorec byl přepočten na bázi šesti atomů kyslíku. $\mathrm{H}_{2} \mathrm{O}$ byla dopočíána na základě teoretického obsahu $1 \mathrm{H}_{2} \mathrm{O}$.

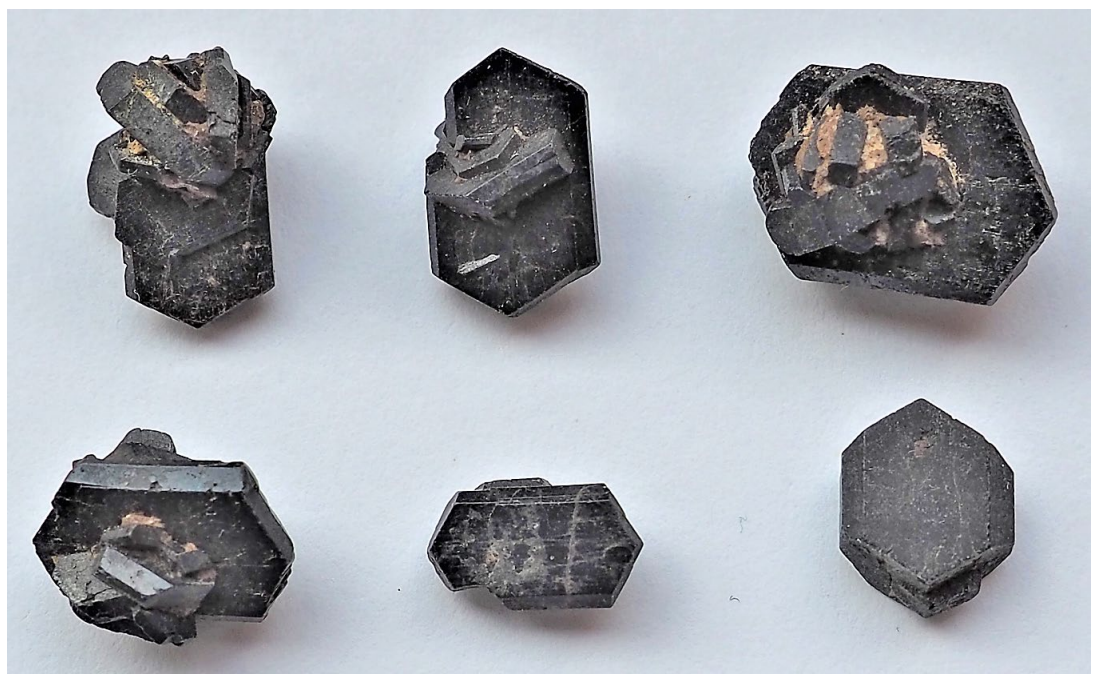

(kolem $1 \mathrm{~mm}$ ), skelně lesklých tabulek. Poměrně estetické křižové srostlice augitu se vyskytují i ve valounech vulkanitů v korytě Ploučnice $v$ údolí pod lokalitou.

\section{Závěr}

Popisovaná zeolitová lokalita je zajímavá především poměrně hojným výskytem böhmitu, který byl $\checkmark$ českých neovulkanitech dosud zaznamenán pouze na třech místech, v Mokré u Žlutic (Černý et al. 2002), Děpoltovicích u Karlových Varů (Sejkora et al. 2010) a na lokalitě Horní Hrad (Pauliš et al. 2015a). Posloupnost krystalizace minerálů $v$ dutinách zdejších vulkanitů Ize zjednodušeně popsat řadou kalcit I $\rightarrow$ phillipsit-K $\rightarrow$ böhmit $\rightarrow$ kalcit II $\rightarrow$ thomsonit-Ca $\rightarrow$ gismondin $\rightarrow$ kalcit III. Samostatně se v dutinách vyskytují analcim (starší) a chabazit-Ca (mladší). Tyto minerály krystalizovaly patrně ze slabě temperovaných roztoků obohacených $\mathrm{Al}$ ionty a alkáliemi, jejichž zdroj Ize najít v alterovaných horninotvorných alumosilikátech (analcim, nefelín).

Svahy lemující údolí Ploučnice mezi Benešovem nad Ploučnicí a Březinami zřejmě přinesou další nálezy böhmitu, respektive minerálů jemu blízkých. Vzhledem k nenápadnosti a možné záměně $s$ jinými minerály nebude patrně popisovaný výskyt böhmitu ojedinělý ani v širším kontextu Českého středohoří.

\section{Poděkování}

Milou povinností autorů je poděkovat za fotografie $B$. Burešovi z Prahy, Z. Dvořákovi z Teplic a P. Zemanovi z Verneřic. Oběma recenzentům (J. Tvrdý a J. Toman) patři dík za podnětné pripomínky, které prispěly ke zvýšení kvality rukopisu. Předložená práce vznikla za finanční podpory Ministerstva kultury ČR $\checkmark$ rámci institucionálního financování výzkumné organizace Národní muzeum (00023272 - cil DKRVO 1.I.c).

Obr. 18 Volné krystaly augitu, lokalita Soutěsky - nad lomem. Velikost největšiho krystalu je 14 × 8 $\mathrm{mm}$, foto Z. Dvorák. 


\section{Literatura}

Bokmimi X, Toledo-Antonio Ja, Guzman-Castillo ML, HerNANDEZ-BELTRAN F (2001) Relationship between crystallite size and bond lengths in boehmite. J Solid State Chem 159: 32-40

Coombs DS, Alberti A, Armbruster t, Artioli G, Colella C, Galli E, Grice JD, Liebau F, Mandarino Ja, Minato H, Nickel EH, Passaglia E, Peacor DR, Quartieri S, Rinaldi R, Ross M, Sheppard RA, TIllmanns E, VezzalinI G (1997) Recommended nomenclature for zeolite minerals: report of the subcommittee on zeolites of the International Mineralogical Association, commission on new minerals and mineral names. Can Mineral 35: 1571-1606

Černý $P$, Černý $P$, Habermann $V$, Koloušek D, Ondruš $P$, VESELOVSKÝ F (2002) Mokrá u Žlutic, lokalita gibbsitu, böhmitu a zeolitů. Minerál 10(6): 403-408

Gatta GD, Cappelletti P, Rotiroti N, Slebodnick C, Rinaldi $R$ (2009) New insights into the crystal structure and crystal chemistry of the zeolite phillipsite. Am Mineral 94: 190-199

Gatta GD, Nestola F, Boffa Ballaran T (2006) Elastic behavior, phase transition, and pressure induced structural evolution of analcime. Am Mineral 91: 568578

KUŽVART M ED (1983) Ložiska nerudních surovin ČSR. Univerzita Karlova Praha

LAUGIER J, BOCHU B (2011) LMGP-suite of programs for the interpretation of X-ray experiments. http://www.ccp14. ac.uk/tutorial/lmgp, přístup duben 2011

Pauliš P, Hrůzek L, Janeček O, Sejkora J, Malíková $R$ (2014) Cowlesit a doprovodná mineralizace z vrchu Hackenberg u České Kamenice (Česká republika). Bull mineral-petrolog Odd Nár Muz (Praha) 22(2): 248-260

Pauliš P, DVořák Z, Svejkovský J, Malíková R, Pour O, Soumar J (2015a) Böhmit z klasického naleziště zeolitů Horní Hrad (Hauenštejn) v Krušných horách (Česká republika). Bull mineral-petrolog Odd Nár Muz (Praha) 23(1): 60-62

Pauliš P, Hrưzek L, Janeček O, Sejkora J, Malíková R, Pour O, FEDIuk F (2015b) Tschernichit, garronit-Ca a doprovodná mineralizace $z$ Jehly u České Kamenice (Česká republika). Bull mineral-petrolog Odd Nár Muz (Praha) 23(2): 147-170
Pauliš P, Hrưzek L, Janeček O, Sejkora J, Malíková R, FeDIUK F (2016a): Zeolitová mineralizace z Nového Oldřichova u Kamenického Šenova (Česká republika). Bull mineral-petrolog Odd Nár Muz (Praha) 24(1): 100-113

Pauliš P, Hrưzek L, Janeček O, Sejkora J, Malíková R, Pour O, Fediuk F (2016b) Zeolitová mineralizace ze Svoru u Nového Boru (Česká republika). Bull mineral -petrolog Odd Nár Muz (Praha) 24, 2: 194-204

Pauliš P. Janeček O, Hrưzek L, Sejkora J, Malíková R, Fediuk F, Pour O (2017) Nordstrandit a zeolitová mineralizace fonolitu Tachovského vrchu u Doks (Česká republika). Bull Mineral Petrolog 25(1): 69-84

Pauliš P, Zeman P, SEJKora J, Malíková R, VRtišKa L, DolNičEK Z, Fediuk F, Pour O (2018a) Zeolitová mineralizace $s$ thomsonitem-Ca $z$ Babětína u Těchlovic v Českém středohoří (Česká republika). Bull Mineral Petrolog 26(1): 1-11

Pauliš P, Zeman P, Zeman V, Sejkora J, Malíková R, Vrtiška L, Dolniček Z, Fediuk F, Pour O, Radoñ M (2018b): Zeolitová mineralizace z Heřmanic u České Lípy (Česká republika). Bull Mineral Petrolog 26(2): 123-137

Pauliš P, Hrưzek L, Sejkora J, Dolniček Z, Malíková R, Ekrt B, Pour O, Fediuk F, JanečEk O (2019) Zeolitová mineralizace ze Zaječího vrchu a Poustevny u Nového Boru (Česká republika). Bull Mineral Petrolog 27(2): 346-370

Pouchou JL, PICHOIR F (1985) "PAP" ( $\varphi \rho Z)$ procedure for improved quantitative microanalysis. In: Microbeam Analysis (J. T. Armstrong, ed.). San Francisco Press, San Francisco: 104-106

RINALdI R, VezZAlinI G (1985) Gismondine: the detailed $\mathrm{x}$-ray structure refinement of two natural symplex. Stud Surf Sci Catal 24: 481-492

Sejkora J, Jebavá I, Plášll J, Bureš B, Tvrdý J (2010) Nordstrandit z lomu v Děpoltovicích u Karlových Varů (Česká republika). Bull mineral-petrolog Odd Nár Muz (Praha) 18(1): 33-41

Stahl K, KVICK A, Smith JV (1990) Thomsonite, a neutron diffraction study at $13 \mathrm{~K}$. Acta Crystallogr Sect C 46 : 1370-1373

Yakubovich OV, Massa W, Gavrilenko PG, Pekov IV (2005) Crystal structure of chabazite. Kristallografiya 50(4): 595-604 